NBER WORKING PAPER SERIES

\title{
DO SAVINGS INCREASE IN RESPONSE TO SALIENT INFORMATION ABOUT RETIREMENT AND EXPECTED PENSIONS?
}

\author{
Mathias Dolls \\ Philipp Doerrenberg \\ Andreas Peichl \\ Holger Stichnoth \\ Working Paper 22684 \\ http://www.nber.org/papers/w22684 \\ NATIONAL BUREAU OF ECONOMIC RESEARCH \\ 1050 Massachusetts Avenue \\ Cambridge, MA 02138 \\ September 2016
}

We thank the Research Data Lab of the German Federal Statistical Agency, especially Stefanie Uhrich, for steady support in accessing the data. Karim Bekhtiar, Sydni M. Pierce, and Christian Skripalle provided excellent research assistance. We are grateful for helpful comments and suggestions by Florian Engelmaier, Hilary Hoynes, Olga Malkova, Katherine Meckel, Sebastian Siegloch and seminar/conference participants at Mannheim, IIPF 2016 and NBER TAPES 2016. The views expressed herein are those of the authors and do not necessarily reflect the views of the National Bureau of Economic Research.

NBER working papers are circulated for discussion and comment purposes. They have not been peer-reviewed or been subject to the review by the NBER Board of Directors that accompanies official NBER publications.

(C) 2016 by Mathias Dolls, Philipp Doerrenberg, Andreas Peichl, and Holger Stichnoth. All rights reserved. Short sections of text, not to exceed two paragraphs, may be quoted without explicit permission provided that full credit, including $\odot$ notice, is given to the source. 
Do Savings Increase in Response to Salient Information about Retirement and Expected Pensions? Mathias Dolls, Philipp Doerrenberg, Andreas Peichl, and Holger Stichnoth

NBER Working Paper No. 22684

September 2016

JEL No. D14,H24,H55,J26

\section{ABSTRACT}

How can retirement savings be increased? We explore a unique policy change in the context of the German pension system to study this question. As of 2004, the German pension authority started to send out annual letters providing detailed and comprehensible information about the pension system and individual expected pension payments. This reform did not change the level of pensions, but only manipulated the knowledge about and salience of expected pension payments. Using German tax return data, we exploit two discontinuities in the age cutoffs of receiving such a letter to study their effects on private retirement savings. Our results show that the letters increase private retirement savings. The effects are fairly sizable and persistent over several years. We further show that the letter increases labor earnings, and that the increase in savings partly crowds out charitable donations. Moreover, we present evidence suggesting that both information and salience drive the savings effect. Our paper adds to a recent literature showing that policies that go beyond the traditional neoclassical reasoning can be powerful to increase savings rates.

Mathias Dolls

ZEW Mannheim

P.O. Box 103443

68034 Mannheim

L 7, 1

68161 Mannheim

dolls@zew.de

Philipp Doerrenberg

ZEW Mannheim

L 7, 1

D-68161 Mannheim

Germany

doerrenberg@zew.de
Andreas Peichl

ZEW and University of Mannheim

L7, 1

68161 Mannheim

Germany

peichl@zew.de

Holger Stichnoth

ZEW Mannheim

L 7, 1

D-68161 Mannheim

Germany

stichnoth@zew.de 


\section{Introduction}

Life expectancies steadily increase and the average age of populations rises in most industrialized countries. This development has severe implications for pension systems and there is concern that individual savings for retirement are not sufficient (Benartzi and Thaler 2013; Poterba 2014). ${ }^{1}$ An important question then is how retirement savings can be increased in order to guarantee adequate old-age income for all individuals. In efforts to improve retirement savings many governments spend large amounts of money to subsidize savings in retirement accounts. The empirical literature regarding the effect of such "traditional" subsidy policies is mixed; individuals' savings behavior does not seem to respond to saving subsidies in the way a neoclassical incentive model would predict (see Chetty 2015 and references therein). A series of recent studies, however, show that "less traditional" policies can be more effective to increase savings. For example, there is robust evidence that changing the default in the decision whether to contribute to a retirement account or not is very effective in increasing savings (Madrian and Shea 2001; Thaler and Benartzi 2004; Chetty et al. 2014).

In this paper, we study another type of "less traditional" policy that may help to increase individual savings for retirement. We explore a policy change in Germany which increased the information about future pensions payments and made the issue of retirement more salient to individuals. The German pension system is complicated and it is therefore difficult to develop precise expectations about future pension payments. ${ }^{2}$ In an effort to increase transparency, the German public pension authority implemented a reform which changed the way information about retirement savings are provided. In particular, as of 2004 the pension authority started to send out annual letters which provide detailed and comprehensible information about the pension system in general and individual expected pension payments. For example, the letters inform recipients about the individual date of statutory retirement and the pension payments that they can currently expect upon retirement. The letters also nudge individuals to save more through private retirement accounts. Importantly, the letter reform did not change the level of retirement payments, but it only manipulated the knowledge about and salience of pension payments.

\footnotetext{
${ }^{1}$ We study the case of Germany, where it is generally acknowledged that more private retirement savings are necessary to maintain an adequate level of income for the elderly (see, for example, the government report in German Federal Government 2012).

${ }^{2}$ For example, using evidence on expected replacement rates of the public pension from the SHARE survey combined with administrative records from the German pension insurance, we show that about two thirds to three quarters of employees tend to overestimate their expected public pension - see Section 6 for details.
} 
We use German tax return data from administrative records to study the effect of information letters on private retirement savings. We use two strategies to identify the effect of the letters: (i) a difference-in-differences (DiD) approach where we exploit two discontinuities in the age cutoffs of receiving such a letter or not. In particular, prior to the 2004 reform, all employees older than 55 already received information about their retirement payments whereas employees younger than 55 did not receive any information. Since those age groups that always received a letter did not experience a shock in information or salience, we use them as a control group for slightly younger age groups who started to receive the letter in the course of the reform. In addition, not all employees were affected by the reform. Subjects eligible to receive the letter are older than 27 years old and have paid social security contributions for at least five years. Younger (or less experienced) individuals can therefore serve as a control group for age groups slightly older than 27 . Using quasirandom variation around these age cutoffs, we rely on a DiD design where we follow the differently affected age groups over time. (ii) As a complement to the DiD design, we follow an event-study approach which uses that, at the young age cutoff, different taxpayers start receiving letters at different points of time. Using withinperson variation over time, we study how savings developed after (and before) a letter is received.

From a neoclassical perspective with full information and purely rational individuals, these letters should not affect retirement savings because incentives remain the same and the amount of future pension payments does not change. ${ }^{3}$ However, the reform relates to recent empirical evidence showing that better information about institutional details and more salient policies can have significant effects on behavior. ${ }^{4}$ In the context of retirement savings, Goda et al. (2014) conduct a randomized field experiment to study the effects of providing income projections along with general planning information about employer-provided retirement accounts. Their results indicate that contributions to the retirement accounts are affected by projections and planning materials, but the projections alone do not have a significant effect. Duflo and Saez (2003) conduct a field experiment in which randomly chosen

${ }^{3}$ Mastrobuoni (2011) shows that in the US context workers do not change their retirement behavior after receiving the annual Social Security Statement. Haupt (2014) reports that $12 \%$ of survey respondents in Germany stated that they increased (or planned to increase) savings upon receiving the information letter. Using administrative data and an identification strategy that allows causal inference, we study if these survey responses translate into actual behavior.

${ }^{4}$ For example, Bhargava and Manoli (2015) use a randomized experiment in the context of the Earned Income Tax Credit (EITC) in the US to show that providing simplified information about the EITC has a significantly positive effect on the take-up of EITC benefits. Finkelstein (2009) provides evidence that a policy which decreased the salience of driving-toll rates affects the elasticity of driving w.r.t. to the toll rates, and Chetty et al. (2009) show that consumers are not responsive to taxes that are not salient. 
individuals are provided monetary incentives to attend seminars that inform about a specific retirement plan. Their findings show that enrollment in the retirement plan increases for treated individuals as well as their peers. Beshears et al. (2015) find that information about the saving behavior of peers affects retirement savings.

Our results show that the information letters affect private retirement savings. The DiD results indicate that receiving the letter increases contributions to a private retirement account. This effect is statistically significant and fairly sizable - about 40 EUR per year at the higher age cutoff and 20 EUR per year at the lower cutoff. These values represent $33 \%$ and $16 \%$, respectively, of the average age-group specific post-reform savings. The effects on other variables such as subsidies received by the government or the amount of deductible expenses are also positive and consistent with our main effect on private retirement contributions. All DiD results are robust to the choice of the age bandwidth. Triple DiDs, where we use other age groups for placebo DiDs, also indicate that the letters increase savings. The results from event study estimates confirm the DiD findings. Our estimates for extensive margin responses show that the share of taxpayers with positive Riester savings increases by $4 \%$-points at the higher age cutoff and 1\%-point at the lower cutoff, relative to the control group. All our findings indicate that the letter effects are smaller, yet significant, at the lower age cutoff compared to the older one; retirement contributions of younger individuals are less responsive to the information. This may either suggest that younger individuals, who are more than 30 years away from retiring, do not plan far ahead, or they do not have sufficient levels of income to save through private retirement accounts.

How are these extra savings afforded and what are the "behavioral" mechanisms behind our results? First, we show that receiving the letters has a negative effect on charitable donations, suggesting that part of the savings response crowds out donations. We also find some evidence that labor supply is increased in response to the letters. Second, we presume that our main results are driven by a combination of information and salience effects. We study married couples to disentangle these two mechanisms. The rationale behind this approach is that the younger couple in a married couple receives the treatment letter after the older partner. Hence, the letter of an older partner makes the issue salient to the younger partner without providing personalized information. Our findings suggest that both mechanisms contribute to the observed effect on private retirement savings.

Our study relates to an increasing literature finding that seemingly irrelevant factors - at least irrelevant in the neoclassical context - can help to improve responsiveness to and compliance with institutional policies (see related literature discussed above). Although the theoretical mechanisms behind many of such findings are still 
not fully understood in the literature, a series of papers, including ours, now provide robust evidence that non-traditional policies such as changing defaults, information provision or the level of salience can have significant effects on retirement savings and, more broadly, individual behavior (see Chetty 2015 for a more detailed discussion on the policy implications of "behavioral" results). The findings in our paper, along with the related literature, have important policy implications. One lesson may be that governments may wish to provide better and more transparent information about their policies in general and about retirement systems in particular in order to achieve desired political goals such as increased savings rates. The particular findings of the pension-payment information letters that we study also inform governments in other countries, which followed the German example and introduced comparable letters. ${ }^{5}$

The paper proceeds as follows. In Section 2, we describe the institutional details of the German pension system and the reform that we exploit in this paper. We provide information about the data, outcome variables and some basic summary statistics in Section 3, and the empirical strategy is discussed in Section 4. Our main results are presented in Section 5. Section 6 discusses potential mechanisms behind the treatment effect, and Section 7 concludes the paper.

\section{Institutional Background}

The retirement system in Germany. The German pension system, which had traditionally been dominated by a public pay-as-you-go (PAYG) scheme (the socalled Bismarckian system which was implemented in the late 19th century), has been transformed into a three-pillar system over the last decades (see 'Riester pension reform' in the next paragraph). ${ }^{6}$ The first pillar comprises the traditional government-organized statutory pension insurance system based on PAYG. The second pillar is based on occupational pension plans, where employers support employees in forming retirement payments. The focus of our paper is on the interaction between receiving information about the first pillar and own contributions to the third pillar: private pension plans, where individuals are themselves responsible for building up financial reserves for retirement.

\footnotetext{
${ }^{5}$ Other countries with similar letters include the USA, Finland, Sweden and France. See Larsson et al. (2009) and the (German-language) overview in Schulz-Weidner (2012).

${ }^{6}$ The mandatory retirement age was 65 during the period of our analysis with few possibilities for early retirement at the age of 63 .
} 
Riester pension plans. In 2001, the German government passed the so-called 'Riester' pension reform (named after Walter Riester who was the minister responsible for the reform) that strengthened the second and third pillar by partially substituting PAYG financed pensions with funded pensions (see Boersch-Supan et al. 2015 for an overview). While insurance through the statutory pension insurance scheme is compulsory for employees in Germany, signing a contract for a private pension scheme in the second and third pillar of the Germany pension system is voluntary. Both the second and third pillar are subsidized to incentivize personal responsibility and compensate for decreasing statutory pensions. For the second pillar, the reform introduced the legal right to convert salary into pension contributions and thus make them exempt from income taxation and social insurance contributions (deferred taxation). For the third pillar, Riester pension plans have been introduced. The contributions to these Riester pension contracts are our outcomes of interest (note that we do not exploit the 2001 reform in our paper; we study the effect of information letters which were sent out since 2004 on Riester contributions). Table 1 gives an overview of the Riester subsidy scheme.

Contributions to a Riester retirement account are directly subsidized with a basic subsidy and an additional child subsidy for individuals with children. ${ }^{7}$ In order to receive the maximum direct subsidy, individuals have to contribute a certain share of their gross earnings to the retirement account. ${ }^{8}$ In addition to the direct subsidy, contributions to Riester pension plans can be deducted from the income tax. ${ }^{9}$ The overall subsidy is the sum of the direct subsidies and the tax allowance. ${ }^{10}$

\footnotetext{
${ }^{7}$ The maximum basic subsidy has been raised from 38 Euro in 2002/2003 to 154 Euro from 2008 onwards. It is twice as large for married couples if they sign two separate Riester contracts. Contributors who have children additionally receive a child subsidy, which was 46 Euro per child in 2002/2003 and has been raised to 185 Euro (300 Euro for children born after 2007).

${ }^{8}$ This contributed amount has to be $4 \%$ (since 2008, it has been increased from $1 \%$ since 2001) of gross earnings but not more than 2100 Euro. Direct subsidies received are counted as part of the contribution. It is possible to contribute more than the maximum amount to the retirement account but that does not increase the subsidy. The subsidies are proportionally reduced if the total contribution (own contribution + direct subsidies) is below the required contribution for the maximum direct subsidies.
}

${ }^{9}$ See Doerrenberg et al. (2016) for an overview of the German personal income tax and deduction possibilities. The deduction is capped at a maximum amount which has been raised from 525 Euro in $2002 / 2003$ to 2100 Euro in 2008. The tax deduction is calculated as the difference between the regular tax burden without a Riester contract and an adjusted tax burden with a Riester contract. The direct subsidy is added to the latter.

${ }^{10}$ For illustrative purposes, consider the following example (Corneo et al. 2015): A childless single has gross earnings of 60,000 Euro in 2008 and the tax rate is 50\%. The regular tax liability without a Riester contract is 30,000 Euro. The maximum subsidized saving amount is 2,100 Euro, i.e. $\min (60,000 \times 0.04,2100)$. In order to receive the maximum basic subsidy of 154 Euro, the own contribution has to be 1,946 Euro $(=2100-154)$. The adjusted tax burden amounts to $(60,000-2,100) \times 0.5+154=29,104$ Euro. The tax allowance then equals $30,000-29,104=896$ Euro, and the overall subsidy is $154+896=1,050$ Euro. 
The treatment: information letters. One important component of the 2001 pension reform was the decision to send out annual pension information letters as of January 2004. The purpose of these letters is to provide a solid basis for retirement planning decisions and to increase awareness for the need of private retirement savings. With their introduction, the German government thus took account of the increased information needs of the population that arose as a consequence of the new structure and more complex design of the German pension system. ${ }^{11}$

The pension information letters are sent to every insured person that fulfills two eligibility criteria: the individual (i) has to be 27 or older and (ii) must have paid social security contributions for at least five years. Civil servants and those self-employed that are not insured in the German statutory pension insurance do not receive information letters. The information letters complement so-called pension statements that have been sent to insured people aged 55 or older already before the introduction of the new letters and that still exist today. Pension statements contain more detailed information, for example on covered earnings, and replace the information letter in three-year intervals at the age of 55, 58, 61 and 64. The new pension information letters have been gradually introduced. The test phase started in the second half of 2002 when one sixth of all eligible people received a letter. In 2003, information letters were sent to another one third of eligible individuals. The test phase ended in 2004 when the remaining $50 \%$ of the insured received a letter. ${ }^{12}$ As of 2005, the statutory pension insurance scheme has sent annual letters to all insured that are eligible. ${ }^{13}$

The letters contain a rich set of information and are written in a comprehensible way - comparable to the annual Social Security Statement in the US (Mastrobuoni 2011). Figures 1, 2, and 3 show an example of an information letter along with explanations of the most relevant parts of the letter. The letter, for example, includes information about the pension an individual would receive today in case of immediate full disability as well as current accrued and expected future pension rights. The latter are calculated based on the assumption that future earnings correspond to the average earnings of the previous 5-year period. In the basic scenario, there is no future adjustment of pensions taken into account. In two additional sce-

\footnotetext{
${ }^{11}$ Haupt (2014) provides survey evidence that Germans indeed think that the pension system is very complex and complicated. Below we show some evidence that a vast majority of individuals tend to overestimate their expected pensions.

${ }^{12}$ Unfortunately, the pension administration did not provide information on the criteria of how individuals were selected into the three different years. Because some individuals have been treated earlier than 2004, we will underestimate the true effect of the pension letters.

${ }^{13}$ Note that pension statements could be requested prior to the reform. Since March 2012, insured people have the additional possibility to access their information letter online at any time. As of 2016, about 42 million information letters are sent out every year.
} 
narios, future accrued pension rights are calculated based on assumed yearly pension adjustments of one and two per cent. It is explicitly stated that future pension adjustments are uncertain from today's perspective and that the adjustment factor does not account for the loss in purchasing power. ${ }^{14}$ The letters further contain information about pension contributions paid so far and resulting earnings points that determine future pension rights. The letter also provides information about the growing pension gap which follows from the fact that future pensions will grow with a lower rate than wages. The importance of additional retirement savings is emphasized together with the note to account for the loss in purchasing power when planning for old-age provision.

\section{Data, Outcomes and Summary Statistics}

Data set. We use the German Taxpayer Panel, an administrative data set collected by German tax authorities. Provided and administered by the German Federal Statistical Office, the data set is based on the universe of personal income tax returns (Kriete-Dodds and Vorgrimler 2007). The unit of observation is the taxpayer, i.e., either a single individual or a couple filing jointly. The data set is a balanced panel covering all German tax units filing tax returns in the period 2001 to 2010. We have access to a $5 \%$ stratified random sample of the Taxpayer Panel and employ the respective population weights provided by the Statistical Office in all calculations. The statistical office only provides the data set as a balanced panel (as a putative service to the researchers), which implies that it only includes taxpayers that file a tax return in all ten years of the panel. The data contain all information necessary to calculate a taxpayer's annual income tax, this includes basic socio-demographic characteristics such as birth date, gender, family status, number of children as well as detailed information on income sources and tax base parameters such as work-related expenses and deductions. ${ }^{15}$

Outcome Variables. We study the effect of the pension information letters on various outcome variables included in the tax return data. The main outcome variable throughout the paper is the contribution to a Riester pension account (excluding subsidies). Because the unit observation is the taxpayer, either singles or couples,

\footnotetext{
${ }^{14}$ The pension adjustment primarily depends on the development of gross wages in Germany. Additional factors that are taken into account are changes in the contribution rate for the German statutory pension insurance scheme and the ratio of contributors and recipients (the latter known as the so-called sustainability factor).

${ }^{15}$ Doerrenberg et al. (2016), for example, use the same data (in the context of the elasticity of taxable income).
} 
in case of married couples our outcome variable is the sum of Riester savings by the wife and the husband. We also study the effects on other variables, some of which are mechanically related with the Riester contributions: total direct subsidies, i.e. the sum of the basic and the child subsidy, the special expense deduction, the tax allowance as well as the total subsidy (see above for the detailed meanings of these variables and how they are related). All outcome variables provide information whether pension information letters induce their recipients to change savings in Riester pension plans at the intensive saving margin. We also explore if the extensive margin of savings, i.e., whether to contribute to the Riester pension scheme account or not, is affected by the information letters.

Note that we do not observe contributions to occupational pension schemes, the second pillar of the German pension system, in the tax data. The reason is that they are directly deducted from gross income by the employer and hence do not appear in the income tax data. To shed some additional light on our findings, we also study if any changes in retirement savings change labor earnings (due to increased labor supply) or come at the expense of altered charitable donations.

Sample selection. The sample is restricted to taxpayers who are between 16 and 70 years of age. We have to exclude a few observations due to data errors; these particularly include individuals with implausible values in demographics (changing date of births or gender). In years were individuals do not report any Riester savings, these variable are coded as zero. Our final sample for analysis includes about 7.15 million observations, implying that we can rely on 715,000 observations per year.

Summary statistics. Table 2 shows summary statistics for the total contributions to the Riester retirement account and the share of all taxpayers who save through this scheme. Given that the reform was implemented in 2001, it is not surprising that the share of Riester savers increased substantially between 2002 and 2010 from $4.8 \%$ to $20.2 \%$. Accordingly, the average total amount contributions to the Riester account also increased during this time span. For example, average contributions (including zeros for individuals who did not have a Riester account) rose from 14 EUR in 2002 to 209 EUR in 2010. The summary statistics for the other savings variables, shown in Table 3, show a similar overall time trend.

The strictly increasing trend over time shows the importance of establishing a credible identification strategy to study the effects of the pension-information letters; a simple before-after analysis will be confounded by the overall time trend. 


\section{Empirical Strategy}

We use two strategies to identify the effect of the information letters on retirement savings. (i) a difference-in-differences (DiD) approach where we exploit that some age groups started to receive letters whereas others either never receive a letter or have already received a letter before the reform. (ii) An event-study design which uses that different taxpayers at the young age cutoff start receiving letters at different points of time.

Note that we do not observe in our tax return data whether an individual actually received a letter. Assignment to treatment (i.e., receiving a letter) is based on the eligibility criteria to receive the letter (in particular age and year) and not actual treatment. ${ }^{16}$ Hence, we might assign someone to the treatment group although she has not received a letter. This implies that we estimate an intention-to-treat (ITT) effect rather than a conventional treatment effect. This ITT underestimates the effect relative to a situation where assignment to the treatment groups is based on actually receiving a letter.

\subsection{Difference-in-Differences}

We use the discontinuities in receiving a treatment letter at the age cutoffs to set up a DiD. For the lower age cutoff, we use the group of individuals between 22 and 26 years old, who never receive a treatment letter, as a control group for individuals, who are between 27 and 30 years old and who are subject to the 2004 reform of sending out information letters. More precisely, we study how the savings behavior of untreated individuals between 22-26 years of age develop over time (2001-2010), and compare this development to the development over time of individuals between 27-30 years old who started to receive letters upon the reform (since 2004). An individual $i$ is in the control group in year $t$ if she is 22-26 years old in $t$, and she is in the treatment group in $t$ if she is 27-30 years in $t$; this implies that we track age groups over time (also see footnote 18). ${ }^{17}$ We define the treatment group like this in order to have comparable subjects in the treatment and control groups in each year. If we had included all (older) workers who started to receive a letter in the course of the reform, we would have compared individuals who are significantly closer to retirement to the control group of relatively young individuals. In robustness checks, we vary the bandwidths around the cutoff; in some regressions, we for example only

\footnotetext{
${ }^{16}$ Note that due to data limitations (our data starts in 2001) we can only check if individuals paid social insurance contributions in 3 years before the 2004 reform.

${ }^{17}$ In the case of couples, we use the age of the older spouse to define the treatment and control status of the couple. Recall that the data set is on the tax-unit level.
} 
compare 26 year old individuals to 27 year old ones.

The approach for the other age cutoff is comparable: We form a control group of individuals who are between 55-60. These individuals have always (before and after the reform) received pension statements and the information letters therefore do not cause a shock in information and salience. The treatment group consists of individuals who are 50-54 years old and started to receive information letters in the course of the reform. We again form age bandwidths in order to have comparable individuals in both groups, and we vary the bandwidths around the cutoff.

The identifying assumptions of our design are usual for any DiD: the savings behavior of control and treatment groups would have developed similarly over time in the absence of the reform. Figures 4 and 5 plot the yearly average private savings of the control and treatment groups over the time span 2001-2010 for the lower and higher age cut off, respectively. ${ }^{18}$ Unfortunately, we do not have more pre-treatment years in our data, but the graphs yet show that the averages developed similarly in treatment and control groups before all eligible individuals started to receive letters in 2004. We discuss the figure and results in more detail in Section 5.

The corresponding DID-regression equation that we estimate reads as follows:

$$
\phi_{i t}=\alpha+\beta \cdot \text { Treat }_{i t}+\delta \cdot(\text { Treat } \cdot \text { Post })_{i t}+\eta_{t}+\mathbf{X}_{i t}+\epsilon_{i t},
$$

where subscripts indicate an individual $i$ in year $t$. The dependent variable $\phi_{i t}$ stands for one of the outcome variables that measure private savings of person $i$ in year $t$ (see above for a description of our outcome variables). Post indicates the years after the reform; this dummy is set equal to one for all years after 2003. Treat is an indicator variable for an individual's treatment status (with Treat $=0$ : control group, and Treat $=1$ : treatment group). An individual $i$ is in the treatment group in year $t$ if she is between 27 and 30 (at the lower cut off) or 50-54 (at the higher age cut off) in this year. Individuals in the control group are 22-26 and 55-60 years old, respectively. ${ }^{19} \eta_{t}$ is a set of year fixed effects. The variable of interest is the interaction between the treatment group indicator and the indicator for the posttreatment years: (Treat. Post). The coefficient, $\delta$, for this interaction indicates the differential evolutions of savings before and after the reform for the respective treatment group relative to its respective control group. That is, these are the usual

\footnotetext{
${ }^{18}$ That is, we collapse private savings by age group and year and plot the resulting averages in each year. Note that this implies that the group of individuals included in each of the averages is not necessarily the same.

${ }^{19}$ That is, we only have comparable persons in our regressions; individuals who are younger than 22 or older than 30 (at the lower cut off) or younger than 50 and older than 60 (at the higher cut off) in year $t$ are not part of the analysis in this year.
} 
DiD coefficients that indicate if savings in the treatment group evolved differently than the control group's savings. We add a vector of control variables $\mathbf{X}_{i t}$ which includes income, marital status, the number of children, and a dummy indicating East vs West Germany. $\epsilon_{i t}$ is an error term. We use standard OLS regressions and cluster standard errors on the taxpayer level.

\subsection{Event Study}

In the DiD approach, we do not track the same individuals over time: for example, individuals included in the 27-30-years group in 2001 are different from those in the 27-30-years group in 2010. This approach is advantageous because comparable people - in terms of age and therefore years until retirement - are in the control and treatment group, respectively. However, the strategy does not allow controlling for time-invariant individual effects. Therefore, as a complement to the DiD approach, we also implement an event study design using within-person variation over time, i.e. controlling for individual fixed effects. Different individuals experience an "event" in different years. By construction, this research design can only be implemented at the young cutoff since at the older cutoffs, all individuals receive the letter in 2004. As before, the sample is restricted to taxpayers who are between 23 and 30 years old. We define an event by constructing a dummy variable indicating if an individual $i$ received a letter in year $t$ for the first time.

Formally, we estimate the following non-parametric regression equation:

$$
\phi_{i t}=\alpha+\sum_{k=-2}^{3} \beta_{k} \cdot \chi_{i(t+k)}+\eta_{t}+\gamma_{i}+\epsilon_{i t}
$$

where $\gamma_{i}$ is a full set of person fixed effects and $\eta_{t}$ are year fixed effects. ${ }^{20}$ As before, $\phi_{i t}$ is the amount of private savings of person $i$ in year $t$. The explanatory variables of interest are the event time indicators, $\chi_{i(t+k)}$, a set of dummy variables that capture the years before and after individual $i$ experienced the event. Dummy $\chi_{i(t+k)}$ equals one if individual $i$ receives a letter in $t-k$ for the first time. The dummy variable indicating the year prior to the reform, $\chi_{i(t-1)}$, is omitted from the estimation, implying that all effects are relative to the year before the reform. The control group for an individual receiving a letter for the first time in a given year consists of individuals who receive the letter in some other year. The identifying assumption behind this approach is that the point of time of receiving the letter is

\footnotetext{
${ }^{20}$ Note that the individual fixed effects along with the year fixed effects implicitly control for age effects. This is important as savings are correlated with age and we have to rule out that we capture the mere effect of becoming older.
} 
not systematically related to retirement-saving behavior. We plot the coefficients of the $\chi$ dummies to detect any pre-trends that could harm this identifying assumption, and to see if, and how quickly, the letters affect savings.

\section{Results}

Unconditional Means over Time. We begin by plotting the raw difference in retirement Riester savings between treatment and control groups around the two age cutoffs (Figures 4 and 5). The figures show the difference in unconditional means, i.e. including zeros for those tax units that did not have a Riester account and not conditioning on any control variables.

The figures show that the groups differ only slightly in the level of (Riester) retirement savings before the reform. At the lower age cutoff, the 27-30 year-olds contribute an average of 15.3 EUR and 18.7 EUR in 2002 and 2003, compared with 9.6 EUR and 12.0 EUR for the 23- to 26-year-olds. The difference increases by only 2 EUR (=7.7 EUR - 5.7 EUR) in the two pre-reform years. The increase is not significantly different from zero, i.e. the common trend assumption cannot be rejected in these two years. In the first two years after the introduction of the pension information letters (2004-2005), the difference then increases to 13.4 EUR. While fairly small in absolute terms, the effect of the letters amounts to $216 \%$ of the difference in the two pre-reform years. Starting in 2006, the difference between treatment and control group becomes even bigger and increases to 32.1 EUR on average over 2006-2010. The increase in the difference compared with the pre-reform period is statistically significant at the $5 \%$ level in all but the last year (2010) of the observation period. ${ }^{21}$ Comparing the entire pre- and post-reform periods results in an unconditional DiD value of 20.5 EUR at the lower cutoff.

At the age cutoff of 55 years, the effect of the pension information letters is even more pronounced (see Figure 5). Here, it is the younger group that has the higher level of retirement savings throughout. Before the reform, the difference amounts to 5.7 EUR in 2002 and to 7.7 EUR in 2003. This is a time when only the 55- to 59-year-olds receive information about their future pensions. By 2004, all 50- to 54-year-olds have received pension information letters for the first time. In this and the following year, the difference between the two groups increases to 16.6 EUR on average. As for the younger age cutoff, the difference becomes much larger

\footnotetext{
${ }^{21}$ In our balanced panel, a tax unit is only included in the data if it is observed in all years from 2001 to 2010. So all 26-year-olds that we observe in 2010 already filed a tax declaration in 2001, at age 17; this is a very small group. Accordingly, the standard errors increase substantially in the later years.
} 
after 2006. The average difference for the years 2006-2010 is 58.5 EUR. Compared with the average pre-reform difference of $6.7 \mathrm{EUR}$, this is an increase by a factor of 8.7. As the restriction that arises from the balancing of the sample is much less important for the older age groups, the difference is estimated precisely even in the last years of the observation period. The simple DiD based on raw means is 39.5 EUR at the older cutoff.

The size of the differences may not appear large at first glance, but they are quite substantial in relative terms. The average amount of Riester savings in the age group 23-30 in the post-reform period is 150.6 EUR. The unconditional DiD effect of 20.5 EUR represents $13.6 \%$ of this average. For the age group 50-59, the post-reform average is $129.5 \mathrm{EUR}$, suggesting that the letter effects corresponds to $30.5 \%$ of the group-specific post average.

DiD Regressions. In a next step, we run DiD regressions with controls for income, residence in West Germany, marital status, and the number of children. We also include year dummies to account for common time-specific effects. The regression results for the lower age cutoff are displayed in Table 5 and the results for the upper cutoff are in Table 6.

The estimates in column 4 of Table 5 are based on the same definition of the treatment and controls groups as in the unconditional DiD estimates discussed above: we compare individuals aged 27-30 (treatment group) with individuals aged 23-26 (control group). The coefficient of interest is the interaction between the treatment and post-reform indicators. The estimate is 23.8, suggesting that the pre-vs-post letter difference in Riester savings is 23.8 EUR larger in the treatment group than in the control group. The regression estimate is very close to the raw DiD estimate of 20.5 EUR.

In the remaining columns 1-3, we reduce the bandwidth around the age cutoff in order to explore if the estimated effect is sensitive to the definition of the treatment and control group. In our strictest definition (column 1), we compare only individuals aged 27 (treatment group) with individuals aged 26 (control group), thereby mitigating concerns about unobserved time-variant influences that are specific to each group. For this narrow age range, we find a treatment effect of 16.1 EUR. ${ }^{22}$

\footnotetext{
${ }^{22}$ To address concerns that the two groups were subject to unobserved age-specific shocks, we also compute (unconditional) triple-difference estimates (DDD). Individuals aged 31-39 are used as a comparison group for the younger age range (23-26). People aged 35-40 are in the fake treatment group, and individuals aged 31-34 are in the fake control group. The DiD estimate in this fake experiment is found to be 13.0, yielding a DDD estimate of 7.5 EUR (=20.5 - 13.0 EUR). For the older age range (50-59), we use people aged 41-49 for the comparison, with individuals aged 41-44 in the fake treatment group. Here, the DDD estimate is found to be 27.8 EUR $(=39.5-11.7)$. So while in both cases the DDD estimates are smaller than the DiD coefficients, the positive savings
} 
As noted above, this effect is relatively sizeable. For the age group 23-29, average Riester savings in the post-reform period are 150.6 EUR per year, so a treatment effect of 23.8 EUR corresponds to $15.8 \%$ of the average. For the narrower age bracket, the effect of 16.1 EUR is still equivalent to $10.7 \%$ of the average.

Turning to the upper age cutoff in Table 6, we see in column 4 that the regression estimate is again very close to the unconditional DiD estimate (42.4 EUR vs. 39.5 EUR). As before, the remaining columns 1-3 are devoted to reducing the bandwidth around the age cutoff that is used to define treatment and control groups. The treatment effect for the strictest comparison (54- vs. 55-year-olds) is 10.8 EUR. The post-reform average for Riester savings among the age group 50-59 is 128.7 EUR, so the treatment effect represents between $8.4 \%$ and $32.9 \%$ of this amount.

Intensive and Extensive Margins. Table 7 shows regression results for the subsample of tax units with positive Riester contributions. For this group, the letter leads to a stronger absolute increase in savings than for the overall sample. At the lower cutoff, we estimate a DiD effect of 40.2 EUR; at the older age cutoff, the DiD estimate is 57.9 EUR. In relative terms, the effect at the intensive margin is a little weaker than the overall effect. Among the group of Riester savers, average post-reform savings are 638.5 EUR per year for the age group 23-30, and 843.1 EUR for the age group 50-59. The treatment effects at the intensive margin correspond to $5.3 \%$ and $9.9 \%$ of these averages.

To assess the reaction at the extensive margin, we estimate DiD regressions in which we use a dummy indicating whether a taxpayer has positive Riester savings as the dependent variable (Table 8). Columns 1 and 2 are devoted to the younger cutoff, while columns 3 and 4 shows coefficients for the upper age cutoff. For younger individuals, the letter increases the probability to have Riester savings by 1\%-point. This estimate is independent of the bandwidth around the age cutoff. At the older cutoff, we see an increase of the probability of being a Riester contributor by $4 \%$ points if the 50-59 year group is considered. Using the smaller bandwidth of one year around the cutoff reduces the coefficient to 1\%-point. As shown in Table 2, the share of Riester savers among all taxpayers was around 5\% in 2002/03 and then rose to about $20 \%$ in 2010. The post-letter average (between 2004 and 2010) is $15.2 \%$. This implies that the increases by $4 \%$-points and 1\%-points in response to the letter represent $26 \%$ and $6.6 \%$ of the post-reform shares.

Other Outcome Variables. Our main results, where we use the contributions to the Riester account, are consistent with the findings for other private savings effect of the letters is confirmed. 
variables variables (as described in Section 3). The regression results for other outcome variables are displayed in Table 9 for the lower age cutoff and Table 10 for the upper cutoff. The effects for all outcome variables are positive and statistically significant at both age cutoffs. We again see that the treatment effects are higher for the older taxpayers relative to the younger ones.

\section{Discussion}

Our analyses so far show that the information letters increase private pension contributions. In this section, we explore some of the mechanisms behind this result and present a few additional findings. In particular, we explore the lagged response that we observe, argue that both salience and information drive the savings effect, document the reaction of other outcomes (labor earnings and charitable donations), and point out that low-income households (for whom the additional savings would be most important) react least strongly to the information letters.

\subsection{Why the stronger increase after 2006?}

Why does in Figures 4-6 the biggest increase occur only in 2006, i.e. two years after the introduction of the information letters? We see three potential reasons for this.

First, government support for Riester pension savings became more generous in this year: while the basic subsidy for a single adult was 76 EUR per year in 2004/2005, the amount increased to 114 EUR in 2006. Likewise, the maximum amount for the special expense deduction was raised from 1,050 to 1,575 EUR. In both cases, the increase amounts to $50 \%$ of the 2005 value. For our two treatment groups, the percentage increase in the (unconditional) DiD estimates between 2005 and 2006 is higher than these $50 \%$ : for the younger age group, the increase is $101 \%$ (from 14.7 to $29.6 \mathrm{EUR}$ ), and for the older age group, we observe an increase of $123 \%$ (from 18.0 to 40.2 EUR). This suggests that the acceleration in 2006 is not entirely driven by the change in the Riester rules - which anyway are the same for both treatment and control group.

A second, complementary explanation for the stronger increase in 2006 is that many people do not immediately change their behavior when they receive the letter. There is a time lag as people collect information about the best savings scheme among the dozens of offers from different financial institutions. While this alone could mainly explain why the reaction in 2005 is a little stronger than in 2004, an explanation for an even bigger time lag might be that some people will not react to the first letter, but only to the second or third one. 
Finally, especially at the younger age cutoff, there could be a composition effect at play that is specific to our dataset. As noted, in the later years of our observation period, the sample size becomes much smaller for the two younger groups because the dataset only includes tax units that file tax declarations in all years from 2001 to 2010. For the 50-to-59-year-olds in 2001, this is hardly a restriction as they are at their prime working age over the ten subsequent years. By contrast, the 27- to 30-year-olds observed in 2010 must have filed a tax declaration already in 2001, when they were between 18 and 21 years old. So in later years the individuals in this group are more likely to have actually received the letter. ${ }^{23}$ They also have higher incomes on average and, by virtue of having been on the labor market for more years, are probably more mature when it comes to making financial decisions.

As shown in Figure 7, an event-study regression exploiting that different individuals receive the letter for the first time in different years confirms that it takes two years before individuals fully respond to the first receipt of the letter. This is in line with both a lagged and a cumulative response, but cannot be driven by the composition effect alone as the event study considers only variation within individuals over time. Reassuringly, the size of the effect based on the event-study strategy is very similar to the DiD estimates.

\subsection{Salience versus Information}

There are two potential mechanisms through which the letter may have an effect on savings: it may present new information about the pension system in general and especially about individuals' own future pension entitlements, and it may make the issue of saving for retirement more salient. We argue in the following that, at least in the context of our application, both mechanisms contribute to the effect.

Information. If individuals had no information or wrong expectations about their future pension level, the information provided in the letter may lead to an adjustment of savings behavior. A natural question to ask is whether the personalized pension information in the treatment letters constitutes a positive or negative shock to pension expectations, relative to the priors and expectations before receiving the letter. If individuals have accurate expectations or if they underestimate the public pension they can expect in old-age, the (first) receipt of the letter should not provide new information nudging people to engage in additional private retirement savings. Things are different, though, if people overestimate their future pension claims.

\footnotetext{
${ }^{23}$ Recall that we do not directly observe this in the data.
} 
Existing evidence on the accuracy of pension expectations in the German context is scarce. Haupt (2014) shows that almost $85 \%$ of the respondents of the German SAVE survey in 2011 state that they find the information on their projected public pension reported in the pension information letter "(very) helpful". Pension projections are considered to be the most important information in the information letter. ${ }^{24}$ This indicates that a significant fraction of respondents had some uncertainty about their pension claims prior to receiving the information letter.

To shed some light on the accuracy of pension expectations, we exploit data from the "Survey of Health, Ageing and Retirement in Europe" (SHARE) that can be linked to administrative records from the German Pension Insurance. ${ }^{25}$ We calculate the expected net pension based on the reported expected net replacement rate and net earnings of the respondents and compare this expected pension with the projected value respondents obtain in their pension information letter. ${ }^{26}$

Table 4 reports the share of survey respondents that overestimate their projected public pension at mandatory (column 1) and expected (column 2) retirement age. We focus on the first two waves of the SHARE survey from 2004 and 2006/2007 as these years correspond with the savings data we exploit in our main empirical analysis. We find that the share of respondents overestimating their projected pension at mandatory retirement age slightly declines from $61.3 \%$ in wave 1 to $57.9 \%$ in wave 2 . Interestingly, this share remains constant at roughly $71 \%$ when we compare respondent's pension expectations with the projected pension at their expected retirement age. Our results suggest that there is a tendency to overestimate pro-

\footnotetext{
${ }^{24}$ Haupt (2014) reports that $77 \%$ of the SAVE respondents find the information on the projected disability pension "helpful" or "very helpful", $60 \%$ the information on potential pension adjustments, $55 \%$ the hint on additional need for private retirement savings, and $48 \%$ the information on the loss in purchasing power.

${ }^{25}$ SHARE is a cross-national panel survey with a focus on the old-age population. The survey contains a question on the expected net replacement rate of the statutory pension insurance. The question reads: "Thinking about the year when you will collect this pension, approximately, what percentage of your last net earnings will your public old age pension amount to?"

${ }^{26}$ The administrative records contain all relevant information on the earnings biography of the SHARE survey respondents and their accumulated pension rights to simulate the projected public pension that appears in the pension information letter. As described above, the letter reports a projected public pension which is based on the current accrued and expected future pension rights assuming that future earnings equal those in the previous 5-year period prior to receiving the letter. In the information letter, it is explicitly stated that social insurance contributions for public health and nursing care and, if applicable, income taxes need to be deducted from the reported gross pension in order to obtain the net pension. Therefore, we simulate both the projected gross and net pension. The projected public pension reported in the information letter is based on the assumption that the insured person retires at the mandatory retirement age. It could be the case, however, that respondents plan to retire before reaching the mandatory retirement age when answering the question on the expected replacement rate of their public pension. In this case, they have to accept deductions due to early retirement. We therefore additionally simulate a projected pension if people retire at their stated expected retirement age.
} 
jected public pensions, even though one should bear in mind the small number of observations $(\mathrm{N}=111$ in wave 1 and $\mathrm{N}=152$ in wave 2$)$.

Salience. In addition to this information channel, the letters may have an effect because they make the issue of retirement savings more salient. Receiving the letter may bring the issue of retirement on the table and nudge people to think about their retirement plan. In principle, salience alone could affect savings even if the letters did not include any new information to the taxpayers. A large literature, especially in behavioral economics, has shown that increased salience and simple nudges affect behavior in many contexts, even in the absence of additional information or changing other things that would matter in a standard economic framework. Many applications that provide evidence on the effectiveness of nudges and salience are based on simple reminder letters, suggesting that the letters that we study may also work similarly (examples of this vast literature include Altmann and Traxler 2014 and Karlan et al. 2016; see also the book by Thaler and Sunstein 2008).

Both channels matter. Additional estimates (now again based on our main data set, the German Taxpayer Panel) suggest that in our application, both channels typically matter for the effect on savings. To show this, we consider only (married) couples, but record the Riester savings of husbands and wives separately instead of adding them up as in our main analysis. We also split the sample into couples in which the husband is older than the wife and couples in which the wife is older.

In Table 11, the dependent variable are the Riester savings of the husband. In couples in which the husband is older than the wife (Panel A), the husband receives the letter before the wife. In these cases, we cannot distinguish between salience and information effects on the husband's savings. The overall effect of the letter is 17.5 EUR in the age range 23-30, and 35.4 EUR in the age range 50-59. In couples in which the wife is older (Panel B), she receives a letter while the husband does not. We nevertheless see a savings' reaction also for the husband, which is consistent with a (pure) salience effect. While this salience effect is statistically significant only for the age group 50-59, a similar analysis for the savings of the wife yields significant DiD estimates for both age groups (Panel B of Table 12). ${ }^{27}$

\footnotetext{
${ }^{27}$ Note that these additional estimates are only suggestive. First, there are cases in which the wife is older than the husband but in which both spouses receive their first information letters in the same year. There are various ways in which we can define the groups so that the salience effect is indeed pure, but then the sample becomes too small to draw meaningful conclusions, especially in the younger age range. Second, we assume that the savings of the husband are only affected by his wife's letter through salience and not through additional information. However, suppose that the letter to the wife reveals that she has less pension payments than expected. This update in information may induce the husband to save more. In the (West) German context this should be
} 


\subsection{Labor earnings go up, charitable donations decrease}

The increased amount of savings in the Riester account may result from a reduction in consumption, an increase in income, or the crowing-out of other forms of savings or of charitable donations. Unfortunately, our dataset only allows us to test two of these channels.

The effects on charitable donations are shown in Table 13. At the lower age cutoff (column 1), the letter leads to a reduction in charitable donations of 8.4 EUR. In light of the savings effect of 23.8 EUR that we found for this group, this result suggests that about one third of the savings response comes at the expense of lower charitable donations. At the upper cutoff (column 2), the coefficient for charitable donations is -25.4 EUR. Given the overall savings effect of 42.4 EUR, this coefficient suggests that more than $50 \%$ of the savings response is driven by reduced charitable donations. However, the coefficient for charitable donations is not statistically significant in this case.

The effects of the letters on gross labor earnings are displayed in Table 14. The results indicate that the treatment letters have a positive effect on gross earnings. This is consistent with the fact that most households used to overestimate their statutory pension entitlements; increasing labor earnings is then one way to directly increase these entitlements but also to finance additional retirement savings. The effect is quite substantial: the DiD estimates are 2520 EUR per year at the lower age cutoff and 1839 EUR at the higher age cutoff. These are the effects at the household level, so for couples this is the effect on the sum of the earnings of both spouses.

\subsection{Poorer households react less strongly}

A major motivation for both the introduction of the Riester pension scheme and the sending out of pension information letters was the concern that statutory pensions alone will no longer be sufficient to guarantee an adequate income during old age. However, low-income households not only have low entitlements in the statutory pension system, but also save relatively little through the Riester scheme, thus leaving a substantial amount of public subsidies on the table. As Corneo et al. (2015) show, "38\% of the aggregate subsidy accrues to the top two deciles of the population, but only $7.3 \%$ to the bottom two" (p.1). This differential take-up is of obvious social policy concern.

Our analysis suggests that the Riester savings of low-income households also

only a relatively minor issue, especially for the older age group, as husbands are typically the main breadwinners. Then again, couples in which the wife is older than husband may be atypical in this respect. 
react less strongly to the introduction of pension information letters (cf. Figure 6). The difference is sizeable: for the older age range, the unconditional DiD estimate in 2006 is close to 60 EUR for households with an annual income of more than 60,000 EUR per year, but only about 20 EUR for households with an income of between 10,000 and 30,000 EUR. ${ }^{28}$ However, these results alone cannot establish whether the difference arises because poorer households cannot afford the additional savings or whether the information letters do not address their informational needs well enough. We leave this question to future research.

\section{Conclusion}

As of 2004, the German pension authority started to send out annual letters that informed about the pension systems and provided personalized information about (expected) future pension payments. These letters presumably increased the level of information about pensions and made the issue of retirement savings more salient, motivating us to hypothesize that contributions to a private retirement account are affected by the letters. In light of a strong positive time trend of retirement savings for all groups of individuals, we exploit two discontinuities in the age cutoffs of receiving such a letter and an event study design to estimate the effect of the letter. Using administrative tax-record data, we find that the letters increase private pension savings. Using average savings in the retirement account as a benchmark, the effects appear quite sizable.

We further find evidence that a substantial part of the increase in savings is due to a crowding out of charitable donations. The letter most likely affects savings by increasing the level of information about the retirement system and the expected pension level and through bringing the topic of retirement savings to the attention of the letter recipients. Using married couples where one partner receives the letter earlier, we find some evidence that the information is the main driver of the effect at the younger age cutoff, while both, information and salience, seem to play a role for the older taxpayers. However, as we discuss, there are shortcomings in the approach, so these last results should be treated with caution.

While disentangling the two channels is certainly desirable to learn more about the behavioral mechanisms behind such a "less traditional" policy, our findings have practical value even in the absence of a proper separation of the two channels. Increasing private retirement savings is a policy goal and most academic economists

\footnotetext{
${ }^{28}$ We do not distinguish by income for the younger age range because there is much less variation here (esp. for the age range 23-26). There is also less reason for concern as incomes at this age are only a weak predictor of life-time incomes.
} 
would agree that it is necessary to maintain retirement systems. Our findings provide guidance how policies could be designed that effectively increase savings. In emphasizing the practical value of our findings even in the absence of a clear-cut identification of the exact mechanisms, we adopt the "pragmatic perspective" of Chetty (2015, page 14) who, in the context of the positive saving effect of default changes, stresses that "given an exogenous policy objective of increasing saving, this empirical finding has practical value even if the underlying behavioral assumptions remain debated."

\section{References}

Altmann, S. and C. Traxler (2014). Nudges at the dentist. European Economic Review 72, $19-38$.

Benartzi, S. and R. H. Thaler (2013). Behavioral economics and the retirement savings crisis. Science $339(6124), 1152-1153$.

Beshears, J., J. J. Choi, D. Laibson, B. C. Madrian, and K. L. Milkman (2015). The effect of providing peer information on retirement savings decisions. The Journal of Finance 70(3), 1161-1201.

Bhargava, S. and D. Manoli (2015). Psychological frictions and the incomplete take-up of social benefits: Evidence from an irs field experiment. American Economic Review 105(11), 3489-3529.

Boersch-Supan, A., T. Bucher-Koenen, M. Coppola, and B. Lamla (2015). Savings in times of demographic change: Lessons from the German experience. Journal of Economic Surveys 29 (4), 807-829.

Boersch-Supan, A., M. Coppola, and A. Reil-Held (2012, April). Riester Pensions in Germany: Design, Dynamics, Targetting Success and Crowding-In. NBER Working Paper 18014.

Chetty, R. (2015). Behavioral economics and public policy: A pragmatic perspective. American Economic Review, Papers and Proceedings 105(5), 1-33.

Chetty, R., J. N. Friedman, S. Leth-Petersen, T. H. Nielsen, and T. Olsen (2014). Active vs. passive decisions and crowd-out in retirement savings accounts: Evidence from denmark. The Quarterly Journal of Economics 129(3), 11411219.

Chetty, R., A. Looney, and K. Kroft (2009). Salience and taxation: Theory and evidence. American Economic Review 99(4), 1145-77. 
Corneo, G., C. Schröder, and J. König (2015). Distributional effects of subsidizing retirement savings accounts: Evidence from Germany. Freie Univ. Berlin, School of Business \& Economics, Discussion Paper 2015/18.

Doerrenberg, P., A. Peichl, and S. Siegloch (2016). The elasticity of taxable income in the presence of deduction possibilities. Journal of Public Economics, -. Forthcoming.

Duflo, E. and E. Saez (2003). The role of information and social interactions in retirement plan decisions: Evidence from a randomized experiment. Quarterly Journal of Economics 118(3), 815-842.

Finkelstein, A. (2009). E-ztax: Tax salience and tax rates. The Quarterly Journal of Economics 124(3), 969-1010.

German Federal Government (2012). Ergaenzender Bericht der Bundesregierung zum Rentenversicherungsbericht 2012 und Gutachten des Sozialbeirats zum Rentenversicherungsbericht 2012 und zum Alterssicherungsbericht 2012. Available online: http://dipbt.bundestag.de/doc/btd/17/117/1711741. pdf.

Goda, G. S., C. F. Manchester, and A. J. Sojourner (2014). What will my account really be worth? experimental evidence on how retirement income projections affect saving. Journal of Public Economics 119, 80 - 92.

Haupt, M. (2014). Die Renteninformation - Eine Evaluation aus verhaltensoekonomischer Perspektive. Sozialer Fortschritt 63, 42-51.

Karlan, D., M. McConnell, S. Mullainathan, and J. Zinman (2016). Getting to the top of mind: How reminders increase saving. Management Science. forthcoming.

Kriete-Dodds, S. and D. Vorgrimler (2007). The German Taxpayer-Panel. Schmollers Jahrbuch 127(3), 497-509.

Larsson, L., A. Sundén, and O. Settergren (2009). Pension information: The annual statement at a glance. OECD Journal: General Papers 3, 131-171.

Madrian, B. C. and D. F. Shea (2001). The power of suggestion: Inertia in 401(k) participation and savings behavior. The Quarterly Journal of Economics 116(4), 1149-1187.

Mastrobuoni, G. (2011). The role of information for retirement behavior: Evidence based on the stepwise introduction of the social security statement. Journal of Public Economics 95(7-8), 913 - 925. 
Poterba, J. (2014). Retirement security in an aging population. American Economic Review, Papers and Proceedings 104 (5), 1-30.

Schulz-Weidner, W. (2012). Altersvorsorgeinformation im europaeischen Vergleich - zwischen Transparenz und Spekulation. Deutsche Rentenversicherung (DRV) 02/2012.

Thaler, R. H. and S. Benartzi (2004). Save more tomorrow: Using behavioral economics to increase employee saving. Journal of Political Economy 112(S1), S164-S187.

Thaler, R. H. and C. R. Sunstein (2008). Nudge. Yale University Press. 


\section{Figures and Tables}

\section{Figures}

Figure 1: The treatment letter: overview
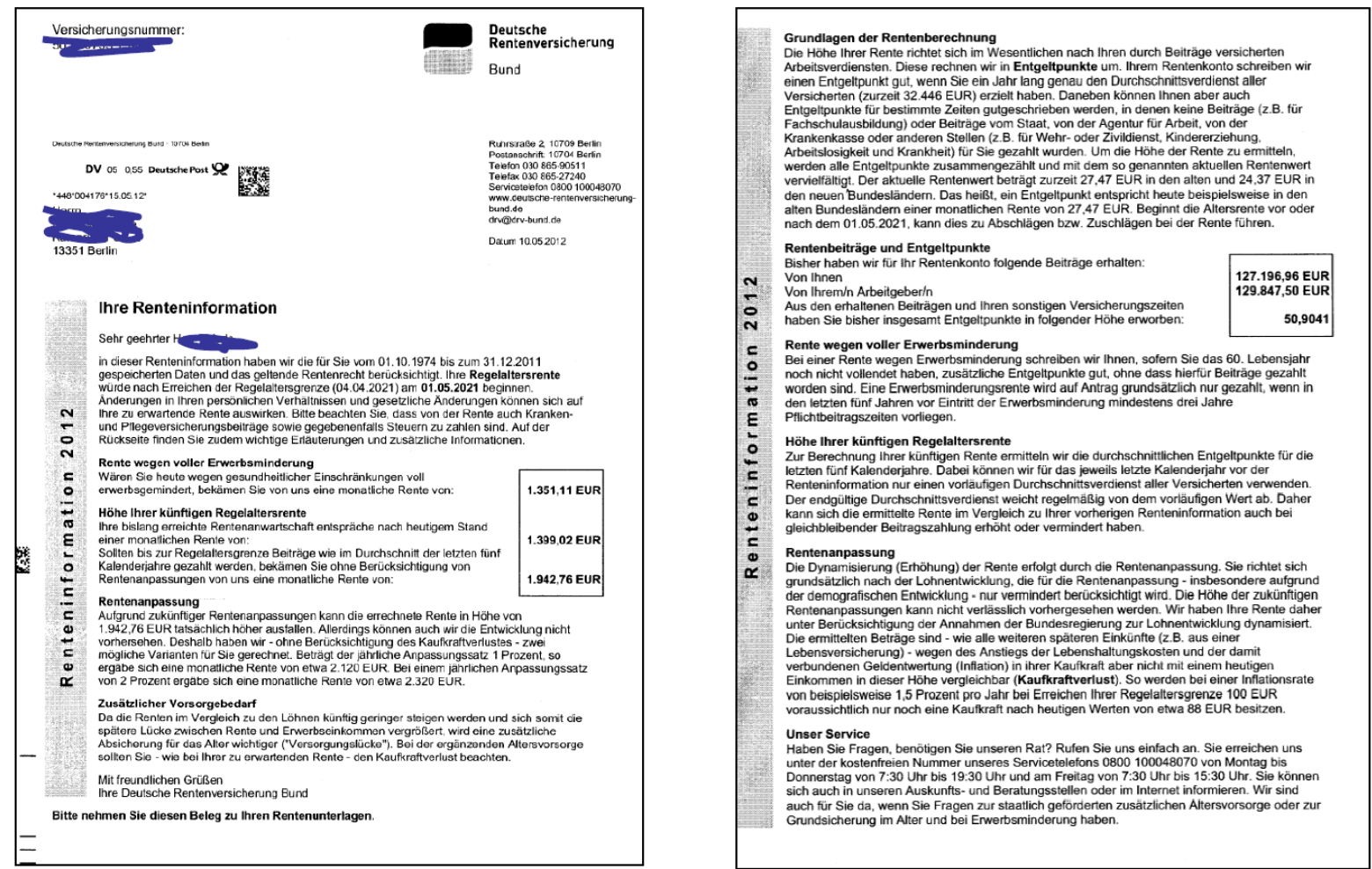

Notes: The Figure depicts an example of an original pension-information letter (in German). 
Figure 2: The treatment letter: explanations (I)

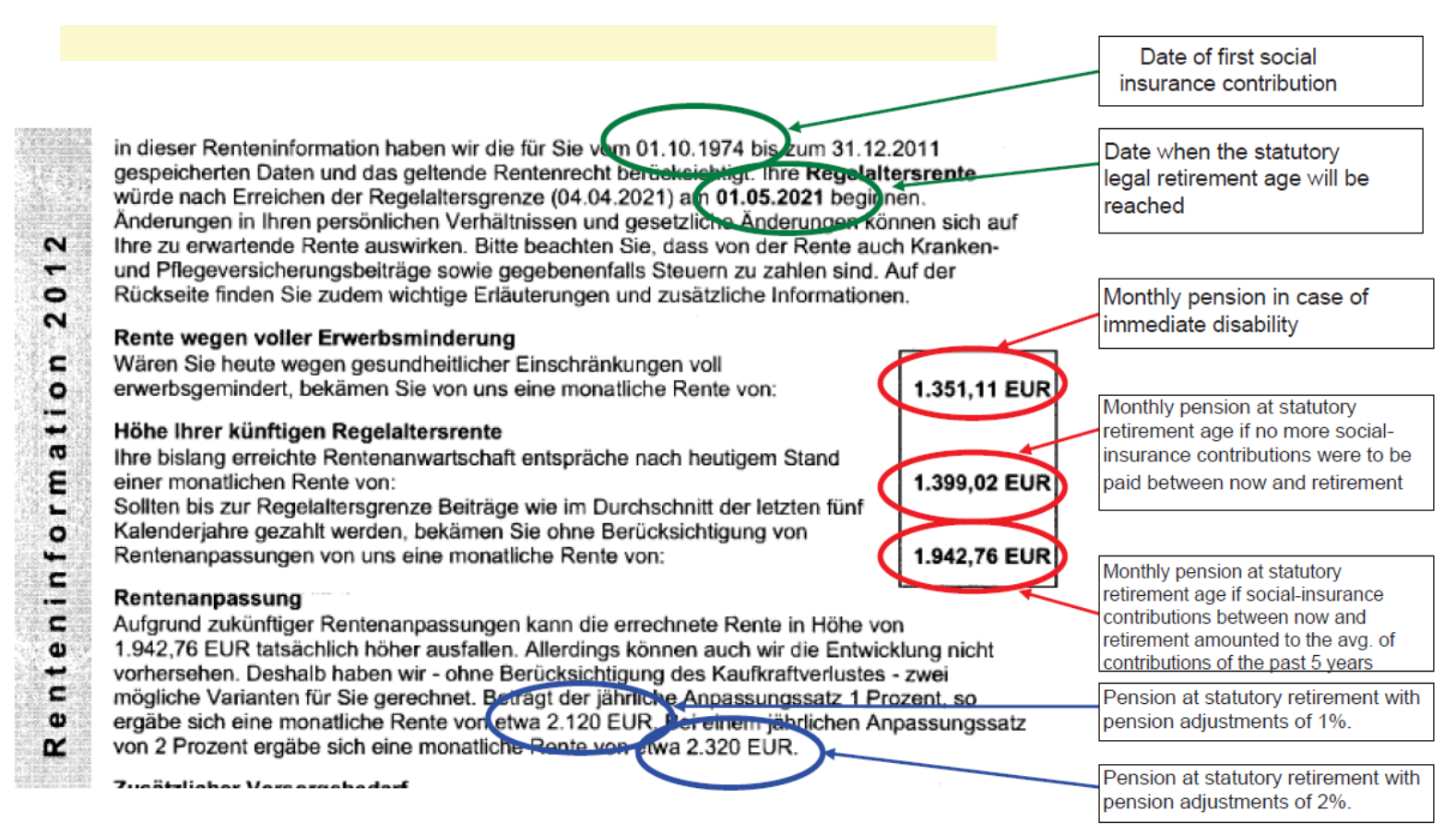

Notes: The Figure provides explanations for some of the most relevant parts of the pension-information letters. 
Figure 3: The treatment letter: explanations (II)

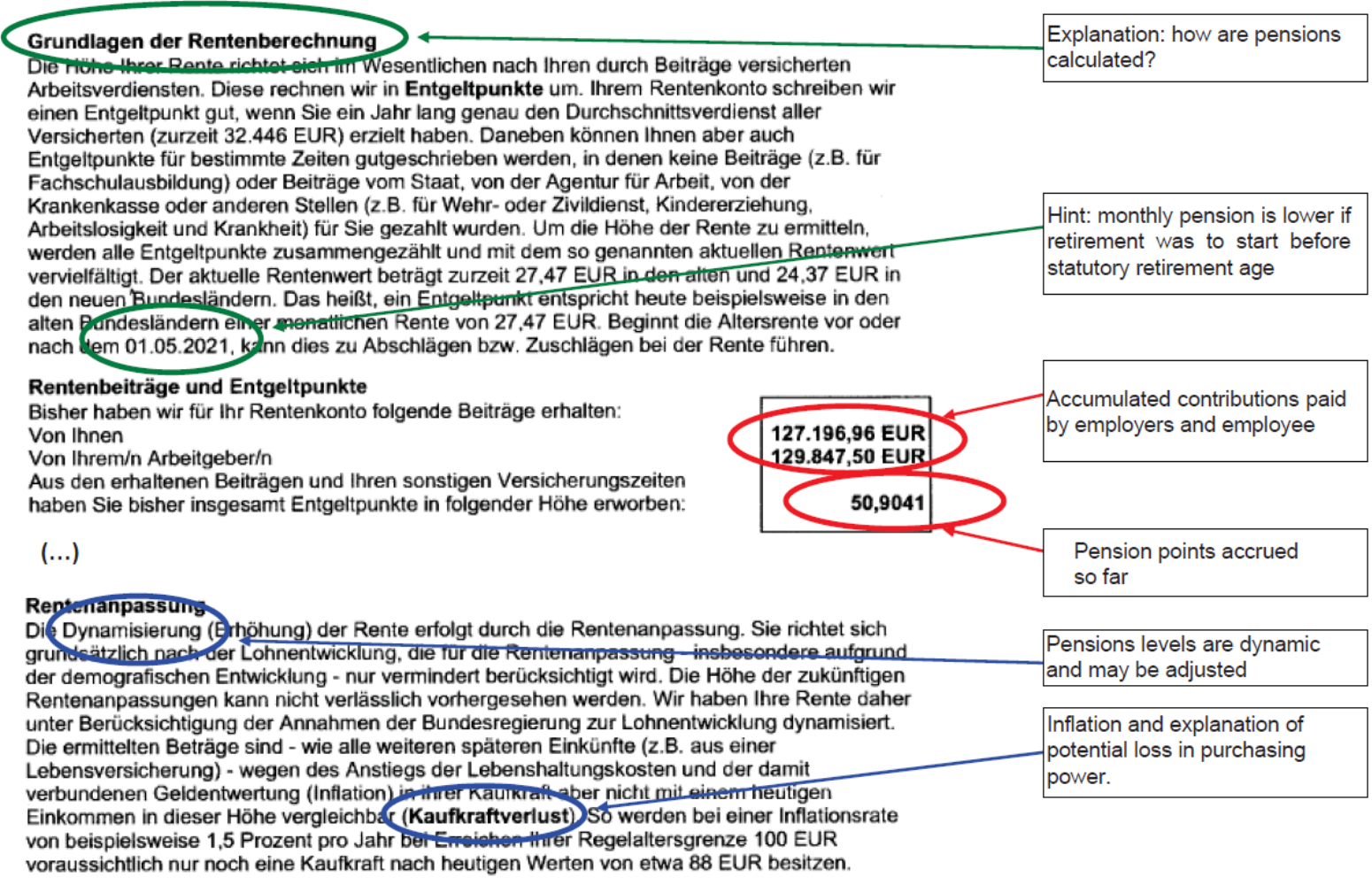

Notes: The Figure provides explanations for some of the most relevant parts of the pension-information letters. 
Figure 4: Raw differences between age groups over time - lower age cutoff

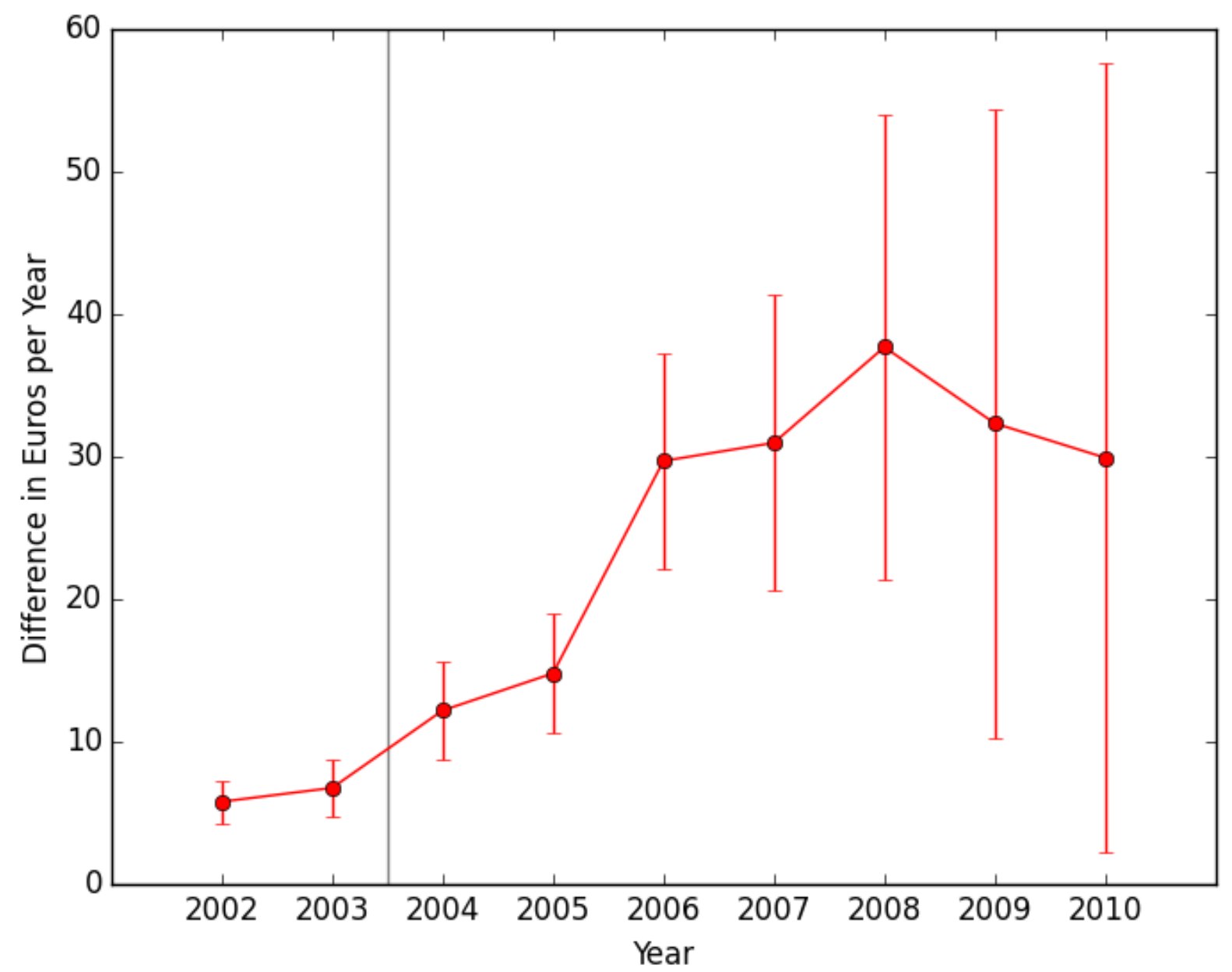

Notes: The Figure depicts the difference in contributions to Riester account between control and treatment group over time. The control group consists of individuals 23-26 years old and the treatment group consists of individuals 27-30 years old. More specifically, the dot in the Figure in year $t$ is based on the difference between the average of individuals who are 27-30 (50-54) in year $t$ and the average of individuals who are 23-26 (55-59) in year $t$. That is, the graph tracks age groups over time. Information letters - the treatment - were started to sent out annually in 2004. The unit is Euro. No control variables included. Data come from German tax returns. 
Figure 5: Raw differences between age groups over time - upper age cutoff

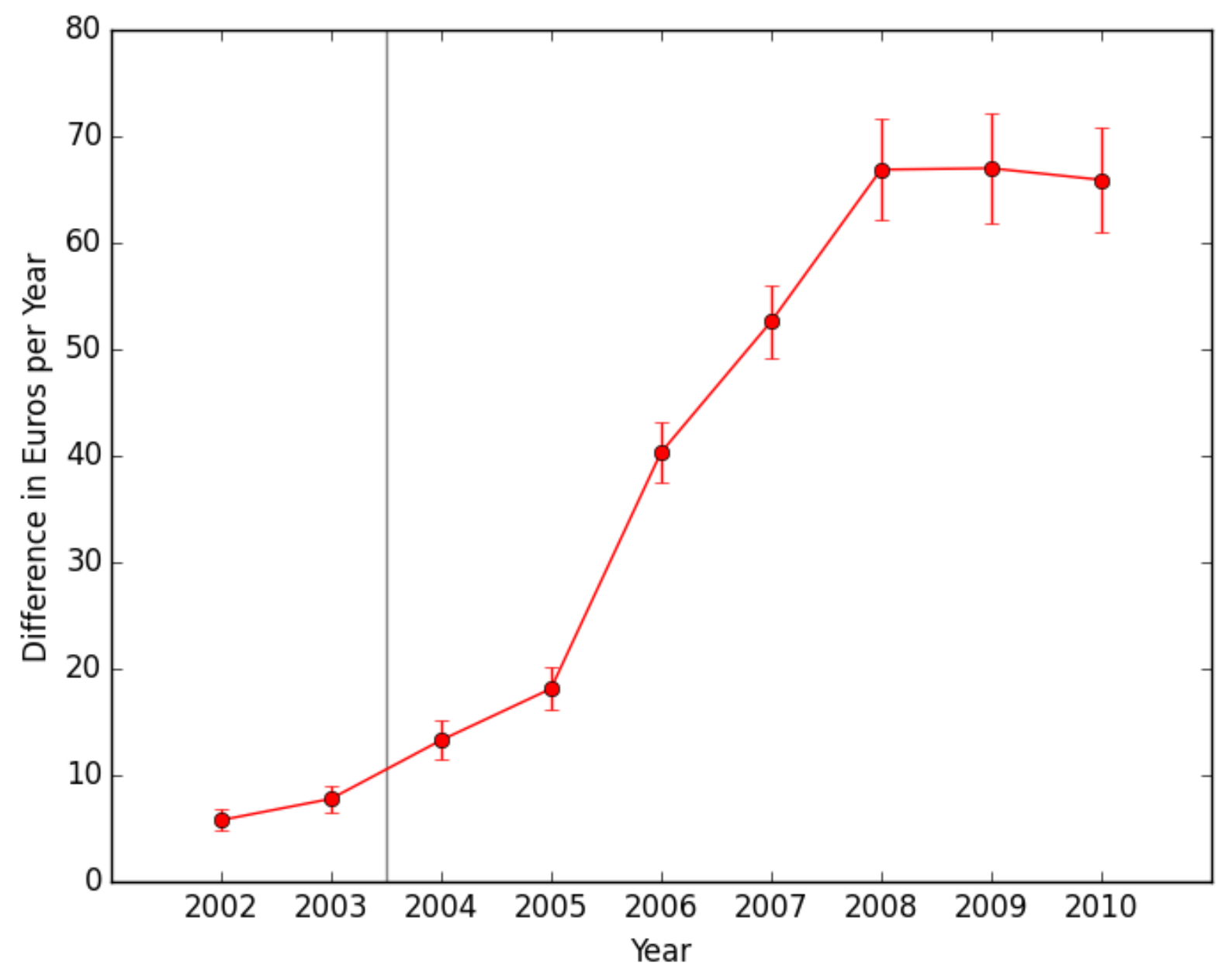

Notes: The Figure depicts the difference in contributions to Riester account between control and treatment group over time. The control group consists of individuals 55-59 years old and the treatment group consists of individuals 50-54 years old. More specifically, the dot in the Figure in year $t$ is based on the difference between the average of individuals who are 27-30 (50-54) in year $t$ and the average of individuals who are 23-26 (55-59) in year $t$. That is, the graph tracks age groups over time. Information letters - the treatment - were started to sent out annually in 2004. The unit is Euro. No control variables included. Data come from German tax returns. 
Figure 6: DiD Graphs: Heterogeneous effects by income - upper age cutoff

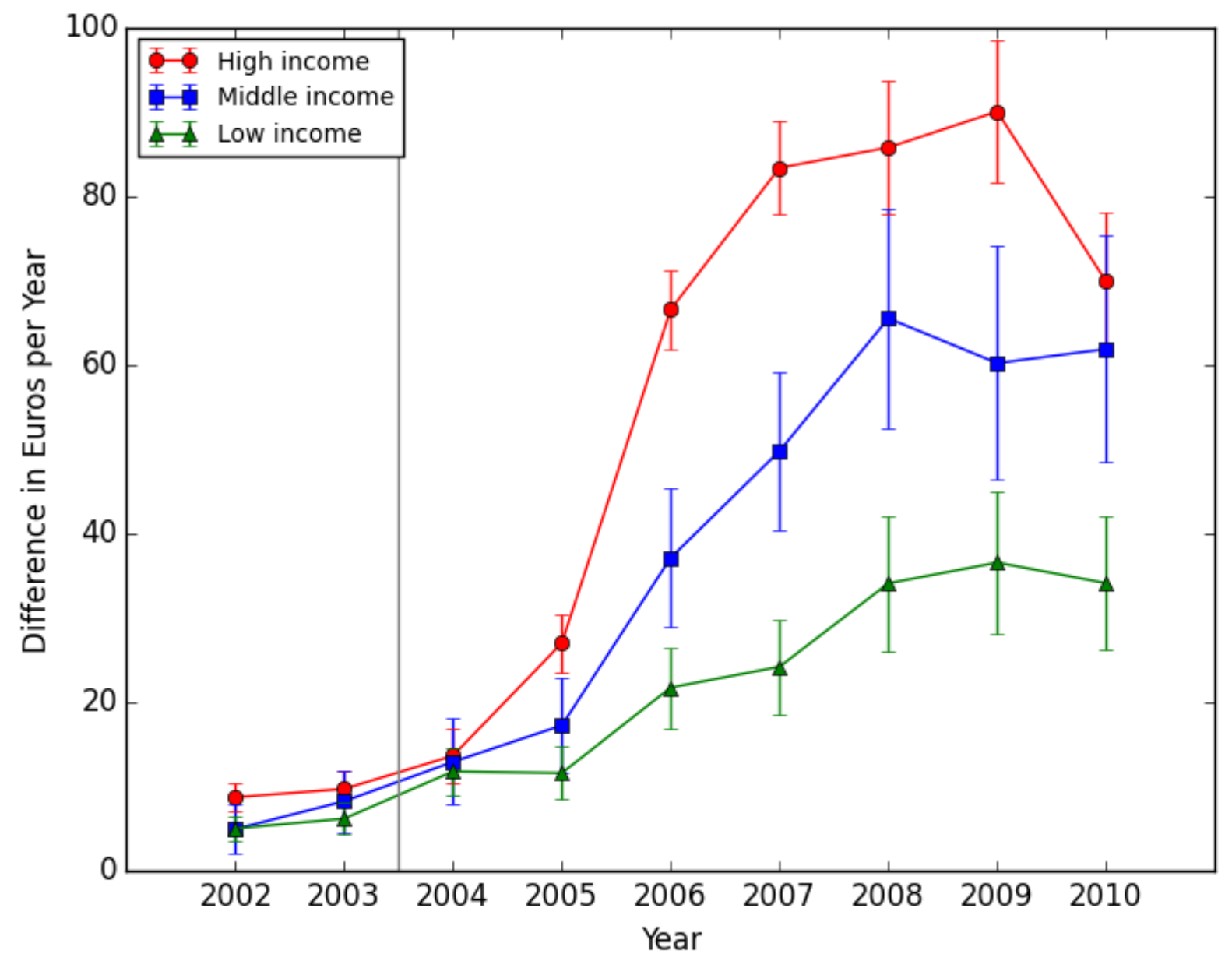

Notes: The Figure documents the heterogeneity of the DiD effects by income. The graphs are from three separate estimations, for households with low (10,000-30,000 euros per year), middle (30,000-60,000 euros) and high (more than 60,000 euros per year) income. Each dot represents the average difference between the treatment group (5054 years old) and the control group (55-59 years old). No control variables included. Information letters - the treatment - were started to sent out annually in 2004. Data source: German Taxpayer Panel (2001-2010). 
Figure 7: Event Study - pre and post letters

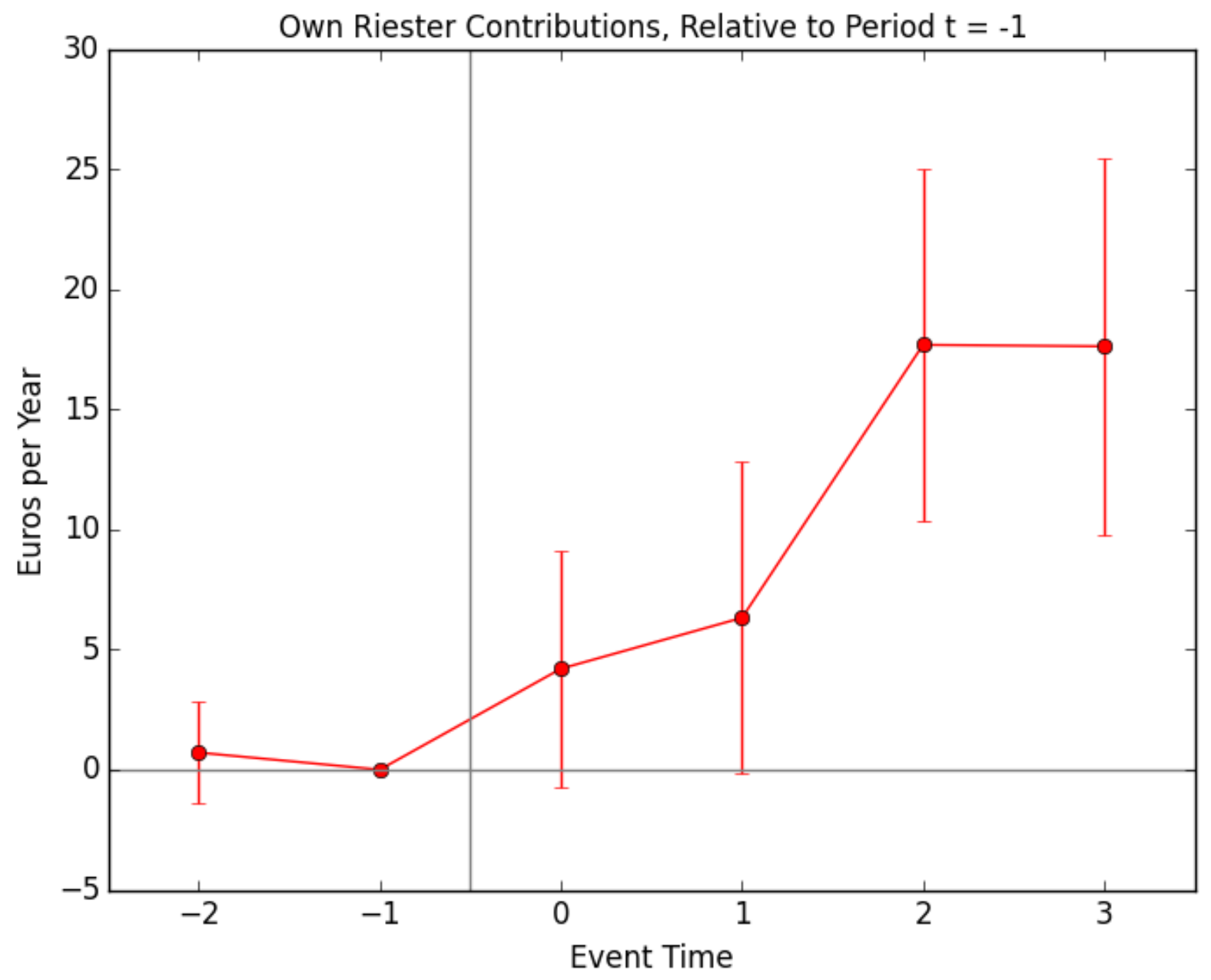

Notes: Event Study based on equation 1. The sample includes individuals between 23 and 30 years old. Outcome variable is contributions to a 'Riester' savings account. 


\section{Tables}

Table 1: Riester subsidy scheme

\begin{tabular}{l|cccc}
\hline \hline Year & $\begin{array}{c}\text { Required contribution for maximum } \\
\text { direct subsidy (\% of gross earnings) }\end{array}$ & $\begin{array}{c}\text { Basic subsidy } \\
\text { (Euro p.a.) }\end{array}$ & $\begin{array}{c}\text { Child subsidy } \\
\text { (Euro p.a.) }\end{array}$ & $\begin{array}{c}\text { Maximum special expense } \\
\text { deduction (Euro p.a.) }\end{array}$ \\
\hline $2002 / 2003$ & 1 & 38 & 46 & 525 \\
$2004 / 2005$ & 2 & 76 & 92 & 1050 \\
$2006 / 2007$ & 3 & 114 & 138 & 1575 \\
since 2008 & 4 & 154 & $185^{*}$ & 2100 \\
\hline \hline
\end{tabular}

Notes: The table is based on Boersch-Supan et al. (2012). Riester contracts require a minimum contribution which has been 60 Euro since 2005. From 2002 to 2004, it was 45 Euro (without children), 38 Euro (one child) or 30 Euro (more than one child). ${ }^{*}$ The child subsidy is 300 Euro for children born after 2007.

Table 2: Riester Savings by year: Average amount and share of savers

\begin{tabular}{lrr}
\hline \hline Year & Riester contributions (EUR) & Share of Riester savers (in \%) \\
\hline 2002 & 14.02 & 04.76 \\
2003 & 19.22 & 05.97 \\
2004 & 37.15 & 07.45 \\
2005 & 48.86 & 09.61 \\
2006 & 93.85 & 13.35 \\
2007 & 124.11 & 16.91 \\
2008 & 181.90 & 18.88 \\
2009 & 195.30 & 19.71 \\
2010 & 208.73 & 20.19 \\
\hline \hline
\end{tabular}

Notes: Summary statistics by year for the average amount of Riester savings (including zeros) and the share (in \%) of individuals with a positive Riester payment. The sample includes all individuals in the data set, $N=715,832$ in each year. 
Table 3: Riester Savings by year: Other savings variables
(1)
$(2)$
(3)
(4)

Dep Var Direct Subsidy Deduction Allowance Total Subsidy

\begin{tabular}{rrrrr}
\hline 2002 & 4.71 & 16.61 & 1.69 & 6.38 \\
2003 & 6.31 & 22.62 & 2.35 & 8.64 \\
2004 & 14.48 & 49.56 & 4.75 & 19.18 \\
2005 & 18.60 & 65.04 & 6.14 & 24.67 \\
2006 & 38.07 & 130.74 & 12.62 & 50.55 \\
2007 & 47.84 & 172.99 & 17.68 & 65.35 \\
2008 & 73.04 & 257.06 & 26.85 & 99.65 \\
2009 & 75.19 & 274.25 & 29.69 & 104.78 \\
2010 & 76.64 & 293.32 & 31.70 & 108.04 \\
\hline
\end{tabular}

Notes: Summary statistics by year for all outcome variables in the regression analyses. (1): total direct subsidies, (2) special expense deduction, (3): tax allowance, (4) total subsidy. All in EUR. The sample includes all individuals in the data set, $N=715,832$ in each year.

Table 4: Pension expectations

\begin{tabular}{l|cc}
\hline \hline Wave/Year & $\begin{array}{c}\text { Share of respondents overestimating projected } \\
\text { pension at mandatory retirement age (in \%) }\end{array}$ & $\begin{array}{c}\text { Share of respondents overestimating projected } \\
\text { pension at expected retirement age (in \%) }\end{array}$ \\
\hline Wave 1 (2004) & 61.3 & 71.2 \\
Wave 2 (2006/2007) & 57.9 & 71.1 \\
\hline \hline
\end{tabular}

Notes: Own calculations based on SHARE and SHARE-RV. The sample consists of non-retired survey respondents in dependent employment who answered the survey questions on the amount of their net income, their expected net replacement rate of the public pension and their expected retirement age and who agreed that their answers to the SHARE survey questions can be linked to administrative records of the German pension insurance (SHARE-RV). $N=111$ in wave 1 and $N=152$ in wave 2. The average age of respondents is 55 (age range from 42 to 64 ) in wave 1 and 56 (age range from 48 to 65 ) in wave 2. 
Table 5: DiD estimates - lower age cutoff - by age bandwidth

\begin{tabular}{lcccc}
\hline \hline & $(1)$ & $(2)$ & $(3)$ & $(4)$ \\
Dep. Variable & Contributions to Retirement & Account \\
Age range & $26-27$ & $25-28$ & $24-29$ & $23-30$ \\
\hline Post $\times$ Treat & $16.08^{* * *}$ & $14.26^{* * *}$ & $19.99^{* * *}$ & $23.81^{* * *}$ \\
& $(2.91)$ & $(2.73)$ & $(2.85)$ & $(2.89)$ \\
& & & & \\
Treat & -0.05 & -0.29 & $-1.49^{* *}$ & $-1.82^{* *}$ \\
& $(1.09)$ & $(0.77)$ & $(0.76)$ & $(0.85)$ \\
West Germany & $9.25^{* * *}$ & $8.05^{* * *}$ & $5.66^{* *}$ & 3.13 \\
& $(3.45)$ & $(3.03)$ & $(2.76)$ & $(2.70)$ \\
Married & $21.77^{* * *}$ & $23.70^{* * *}$ & $22.93^{* * * *}$ & $28.96^{* * *}$ \\
& $(5.39)$ & $(4.45)$ & $(3.69)$ & $(3.61)$ \\
Children & $-16.88^{* * *}-21.03^{* * *}-22.39^{* * *}$ & $-25.49^{* * *}$ \\
& $(5.45)$ & $(4.53)$ & $(3.93)$ & $(3.65)$ \\
Income & $1.40^{*}$ & $1.11^{*}$ & $1.44^{* *}$ & $1.66^{* *}$ \\
& $(0.82)$ & $(0.62)$ & $(0.70)$ & $(0.65)$ \\
\hline Treat group & 27 & $27-28$ & $27-29$ & $27-30$ \\
Year F.E. & yes & yes & yes & yes \\
Pre years & $2001-02$ & $2001-02$ & $2001-02$ & $2001-02$ \\
Post years & $2004-10$ & $2004-10$ & $2004-10$ & $2004-10$ \\
\hline Adj. $R^{2}$ & 0.10 & 0.10 & 0.11 & 0.11 \\
Obs. & 42709 & 88204 & 137147 & 185261 \\
\hline \hline
\end{tabular}

Notes: $\mathrm{DiD}$ regressions based on equation 1. Outcome variable: Contributions to private retirement account ('Riester'). Lower age cutoff. The treatment is receiving a pension information letter. Different age bandwidths around the cutoff to define treatment and control group: 26 vs $27 ; 25-26$ vs. $27-28 ; 24-26$ vs. $27-29 ; 23-26$ vs $27-30$. The treatment letters were started to sent out to all eligible individuals since 2004. There was a test phase before and we therefore exclude the year 2003 from the estimations, implying that pre-reform years include 2001 and 2002, while post-reform years are 2004-2010. The explanatory variable of interest is the interaction between the treatment indicator and the dummy indicating the post-reform years. This coefficient estimates the differential evolution in private retirement savings between the treatment and control group after the treatment. Coefficients measure the effect in Euro. Standard errors in parentheses are robust and clustered on the tax unit level. Significance levels are ${ }^{*}<0.1,{ }^{* *}<0.05,{ }^{* * *}<$ 0.01. Data come from German tax returns, 2001-2010. 
Table 6: DiD estimates - higher age cutoff - by age bandwidth

\begin{tabular}{lcccc}
\hline \hline & $(1)$ & $(2)$ & $(3)$ & $(4)$ \\
Dep. Variable & Contributions to Retirement & Account \\
Age Range & $54-55$ & $53-56$ & $52-57$ & $50-59$ \\
\hline Post $\times$ Treat & $10.77^{* * *}$ & $17.51^{* * *}$ & $26.02^{* * *}$ & $42.41^{* * *}$ \\
& $(2.20)$ & $(1.90)$ & $(2.01)$ & $(2.00)$ \\
& \multicolumn{5}{c}{} \\
Treat & -2.45 & -0.75 & -0.70 & $-1.41^{* *}$ \\
& $(1.52)$ & $(0.88)$ & $(0.66)$ & $(0.55)$ \\
West Germany & $-52.28^{* * *}-51.07^{* * *}-49.62^{* * *}$ & $-48.05^{* * *}$ \\
& $(3.71)$ & $(3.33)$ & $(3.01)$ & $(2.55)$ \\
Married & $42.07^{* * *}$ & $41.13^{* * *}$ & $39.90^{* * *}$ & $39.52^{* * *}$ \\
& $(2.97)$ & $(2.63)$ & $(2.38)$ & $(2.00)$ \\
Children & $44.95^{* * *}$ & $43.58^{* * *}$ & $43.36^{* * *}$ & $42.78^{* * *}$ \\
& $(3.27)$ & $(2.89)$ & $(2.59)$ & $(2.14)$ \\
Income & $0.61^{* * *}$ & $0.49^{* * *}$ & $0.50^{* * *}$ & $0.47^{* * *}$ \\
& $0.12)$ & $(0.12)$ & $(0.09)$ & $(0.09)$ \\
\hline Treat group & 54 & $53-54$ & $52-54$ & $50-54$ \\
Year F.E. & yes & yes & yes & yes \\
Pre years & $2001-02$ & $2001-02$ & $2001-02$ & $2001-02$ \\
Post years & $2004-10$ & $2004-10$ & $2004-10$ & $2004-10$ \\
\hline Adj. $R^{2}$ & 0.05 & 0.05 & 0.05 & 0.05 \\
Obs. & 327991 & 666450 & 1000868 & 1634586 \\
\hline \hline
\end{tabular}

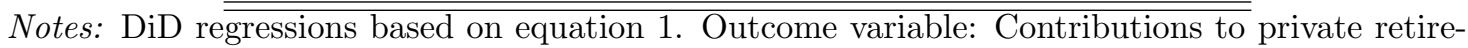
ment account ('Riester'). Higher age cutoff. The treatment is receiving a pension information letter. Different age bandwidths around the cutoff to define treatment and control group: 54 vs 55 ; $53-54$ vs $55-56$; $52-54$ vs $55-57 ; 50-54$ vs $55-59$. The treatment letters were started to sent out to all eligible individuals since 2004. There was a test phase before and we therefore exclude the year 2003 from the estimations, implying that pre-reform years include 2001 and 2002, while postreform years are 2004-2010. The explanatory variable of interest is the interaction between the treatment indicator and the dummy indicating the post-reform years. This coefficient estimates the differential evolution in private retirement savings between the treatment and control group after the treatment. Coefficients measure the effect in Euro. Standard errors in parentheses are robust and clustered on the tax unit level. Significance levels are ${ }^{*}<0.1,{ }^{* *}<0.05,{ }^{* * *}<0.01$. Data come from German tax returns, 2001-2010. 
Table 7: DiD estimates - lower and higher age cutoff - Contributions to Riester retirement account - Conditional on positive Riester contributions

(1) (2)

Dep. Variable Riester retirement contributions

\begin{tabular}{lll} 
Age range & $23-30$ & $50-59$ \\
\hline Post $\times$ Treat & $40.24^{* * *}$ & $57.91^{*}$ \\
& $(15.47)$ & $(29.95)$ \\
Treat & $35.31^{* *}$ & $-54.15^{*}$ \\
& $(14.50)$ & $(28.61)$ \\
West Germany & $108.60^{* * *}$ & $240.89^{* * *}$ \\
& $(15.04)$ & $(12.17)$ \\
Married & -28.12 & $38.52^{* * *}$ \\
& $(32.14)$ & $(14.77)$ \\
Children & $-144.13^{* * *}$ & $-168.56^{* * *}$ \\
& $(23.54)$ & $(10.99)$ \\
Income & $107.58^{* * *}$ & $23.07^{* * *}$ \\
& $(16.15)$ & $(4.46)$ \\
\hline Treat group & $27-30$ & $50-54$ \\
Year F.E. & yes & yes \\
Pre years & $2001-02$ & $2001-02$ \\
Post years & $2004-10$ & $2004-10$ \\
\hline Adj. $R^{2}$ & 0.282 & 0.123 \\
Obs. & 19997 & 189749 \\
\hline
\end{tabular}

Notes: DiD regressions based on equation 1. Outcome variable: Contributions to Riester retirment account. Sample restricted to taxpayers with positive Riester contributions. Lower and upper age cutoff. The treatment is receiving a pension information letter. Treatment and control ages: $23-26$ vs $27-30 ; 50-54$ vs $55-59$. The treatment letters were started to sent out to all eligible individuals since 2004. There was a test phase before and we therefore exclude the year 2003 from the estimations, implying that pre-reform years include 2001 and 2002, while post-reform years are 2004-2010. The explanatory variable of interest is the interaction between the treatment indicator and the dummy indicating the post-reform years. This coefficient estimates the differential evolution in private retirement savings between the treatment and control group after the treatment. Coefficients measure the effect in Euro. Standard errors in parentheses are robust and clustered on the tax unit level. Significance levels are ${ }^{*}<0.1,{ }^{* *}<0.05,{ }^{* * *}<0.01$. Data come from German tax returns, 2001-2010. 
Table 8: DiD estimates - lower and higher age cutoff - extensive margin

\begin{tabular}{lcccc}
\hline \hline \multirow{2}{*}{ Dep. Variable } & $(1)$ & $(2)$ & $(3)$ & $(4)$ \\
& \multicolumn{5}{c}{ Extensive Margin } \\
& Contributing to Retirement Account \\
Age range & $23-30$ & $26-27$ & $50-59$ & $54-55$ \\
\hline Post $\times$ Treat & $0.01^{* *}$ & $0.01^{* * *}$ & $0.04^{* * *}$ & $0.01^{* *}$ \\
& $(0.00)$ & $(0.00)$ & $(0.00)$ & $(0.00)$ \\
& & & & \\
Treat & -0.00 & 0.00 & $0.00^{* * *}$ & 0.00 \\
& $(0.00)$ & $(0.00)$ & $(0.00)$ & $(0.00)$ \\
West Germany & $-0.04^{* * *}$ & $-0.04^{* * *}$ & $-0.10^{* * *}$ & $-0.11^{* * *}$ \\
& $(0.00)$ & $(0.01)$ & $(0.00)$ & $(0.00)$ \\
Married & $0.02^{* * *}$ & $0.02^{* * *}$ & $0.03^{* * *}$ & $0.03^{* * *}$ \\
& $(0.00)$ & $(0.01)$ & $(0.00)$ & $(0.00)$ \\
Children & $0.02^{* * *}$ & $0.02^{* *}$ & $0.06^{* * *}$ & $0.06^{* * *}$ \\
& $(0.00)$ & $(0.01)$ & $(0.00)$ & $(0.00)$ \\
Income & $0.00^{* *}$ & $0.00^{*}$ & $0.00^{* *}$ & 0.00 \\
& $(0.00)$ & $(0.00)$ & $(0.00)$ & $(0.00)$ \\
\hline Treat group & $27-30$ & 27 & $50-54$ & 54 \\
Year F.E. & yes & yes & yes & yes \\
Pre years & $2001-02$ & $2001-02$ & $2001-02$ & $2001-02$ \\
Post years & $2004-10$ & $2004-10$ & $2004-10$ & $2004-10$ \\
\hline Adj. $R^{2}$ & 0.11 & 0.10 & 0.07 & 0.07 \\
Obs. & 185261 & 42709 & 1634586 & 327991 \\
\hline
\end{tabular}

Notes: DiD regressions based on equation 1. Outcome variable: Dummy variable indicating positive contributions to private retirement account ('Riester'). Lower age and upper cutoff. The treatment is receiving a pension information letter. Different age bandwidths around the cutoff to define treatment and control group: 26 vs $27 ; 23-26$ vs $27-30 ; 54$ vs $55 ; 50-54$ vs $55-59$. The treatment letters were started to sent out to all eligible individuals since 2004 . There was a test phase before and we therefore exclude the year 2003 from the estimations, implying that pre-reform years include 2001 and 2002, while post-reform years are 2004-2010. The explanatory variable of interest is the interaction between the treatment indicator and the dummy indicating the post-reform years. This coefficient estimates the differential evolution in private retirement savings between the treatment and control group after the treatment. Coefficients measure the effect in Euro. Standard errors in parentheses are robust and clustered on the tax unit level. Significance levels are ${ }^{*}<0.1,{ }^{* *}<0.05,{ }^{* * *}<0.01$. Data come from German tax returns, 2001-2010. 
Table 9: DiD estimates - lower age cutoff - different savings variables

(1) (2) (3) (4)

Dep. Variable Direct Subsidy Deduction Allowance Total Subsidy

\begin{tabular}{lcccc} 
Age range & $23-30$ & $23-30$ & $23-30$ & $23-30$ \\
\hline Post $\times$ Treat & $6.21^{* * *}$ & $30.28^{* * *}$ & $6.38^{* * *}$ & $12.53^{* * *}$ \\
& $(0.55)$ & $(3.20)$ & $(0.65)$ & $(1.03)$ \\
Treat & & & & \\
& $-4.71^{* * *}$ & $-7.24^{* * *}$ & $1.25^{* * *}$ & $-3.45^{* * *}$ \\
West Germany & $(0.25)$ & $(0.96)$ & $(0.20)$ & $(0.34)$ \\
& $-4.46^{* * *}$ & -1.85 & $4.74^{* * *}$ & 0.37 \\
Married & $(0.66)$ & $(3.14)$ & $(0.58)$ & $(1.02)$ \\
& $13.59^{* * *}$ & $42.17^{* * *}$ & $2.30^{* * *}$ & $15.86^{* * *}$ \\
Children & $(0.77)$ & $(4.05)$ & $(0.82)$ & $(1.32)$ \\
& $28.72^{* * *}$ & 6.07 & $-17.31^{* * *}$ & $11.33^{* * *}$ \\
Income & $1.15)$ & $(4.39)$ & $(0.76)$ & $(1.51)$ \\
& $0.07^{* *}$ & $1.67^{* *}$ & $0.60^{* *}$ & $0.66^{* *}$ \\
Treat group & $(0.03)$ & $(0.66)$ & $(0.23)$ & $(0.26)$ \\
Year F.E. & $27-30$ & $27-30$ & $27-30$ & $27-30$ \\
Pre years & yes & yes & yes & yes \\
Post years & $2001-02$ & $2001-02$ & $2001-02$ & $2001-02$ \\
\hline Adj. $R^{2}$ & $2004-10$ & $2004-10$ & $2004-10$ & $2004-10$ \\
Obs. & 0.14 & 0.13 & 0.08 & 0.12 \\
\hline
\end{tabular}

Notes: DiD regressions based on equation 1. Outcome variables: (1): total direct subsidies, (2) special expense deduction, (3): tax allowance, (4) total subsidy. Lower age cutoff. The treatment is receiving a pension information letter. Treatment and control ages: $23-26$ vs 27-30. The treatment letters were started to sent out to all eligible individuals since 2004. There was a test phase before and we therefore exclude the year 2003 from the estimations, implying that pre-reform years include 2001 and 2002, while post-reform years are 2004-2010. The explanatory variable of interest is the interaction between the treatment indicator and the dummy indicating the post-reform years. This coefficient estimates the differential evolution in private retirement savings between the treatment and control group after the treatment. Coefficients measure the effect in Euro. Standard errors in parentheses are robust and clustered on the tax unit level. Significance levels are ${ }^{*}<0.1,{ }^{* *}<0.05,{ }^{* * *}<0.01$. Data come from German tax returns, 2001-2010. 
Table 10: DiD estimates - higher age cutoff - different savings variables
(1)
(2)
(3)
(4)

Dep. Variable Direct Subsidy Deduction Allowance Total Subsidy

\begin{tabular}{lllll} 
Age range & $50-59$ & $50-59$ & $50-59$ & $50-59$ \\
\hline Post $\times$ Treat & $19.76^{* * *}$ & $63.84^{* * *}$ & $6.46^{* * *}$ & $26.16^{* * *}$ \\
& $(0.53)$ & $(2.28)$ & $(0.41)$ & $(0.78)$
\end{tabular}

\begin{tabular}{lllll} 
Treat & $-3.51^{* * *}$ & $-4.87^{* * *}$ & $0.83^{* * *}$ & $-2.67^{* * *}$ \\
& $(0.17)$ & $(0.57)$ & $(0.09)$ & $(0.21)$ \\
West Germany & $-7.21^{* * *}$ & $-52.76^{* * *}$ & $-4.64^{* * *}$ & $-11.67^{* * *}$ \\
& $(0.58)$ & $(2.87)$ & $(0.51)$ & $(0.92)$ \\
Married & $22.82^{* * *}$ & $66.91^{* * *}$ & $1.95^{* * *}$ & $24.66^{* * *}$ \\
& $(0.40)$ & $(2.23)$ & $(0.47)$ & $(0.75)$ \\
Children & $51.87^{* * *}$ & $96.43^{* * *}$ & $-4.76^{* * *}$ & $46.96^{* * *}$ \\
& $(0.65)$ & $(2.54)$ & $(0.43)$ & $(0.89)$ \\
Income & $0.02^{* * *}$ & $0.43^{* * *}$ & $0.22^{* * *}$ & $0.24^{* * *}$ \\
& $(0.01)$ & $(0.08)$ & $(0.04)$ & $(0.04)$ \\
\hline Treat group & $50-54$ & $50-54$ & $50-54$ & $50-54$ \\
Year F.E. & yes & yes & yes & yes \\
Pre years & $2001-02$ & $2001-02$ & $2001-02$ & $2001-02$ \\
Post years & $2004-10$ & $2004-10$ & $2004-10$ & $2004-10$ \\
\hline Adj. $R^{2}$ & 0.11 & 0.07 & 0.03 & 0.08 \\
Obs. & 1634586 & 1634586 & 1634586 & 1634586 \\
\hline
\end{tabular}

Notes: DiD regressions based on equation 1. Outcome variables: (1): total direct subsidies, (2) special expense deduction, (3): tax allowance, (4) total subsidy. Upper age cutoff. The treatment is receiving a pension information letter. Treatment and control ages: 50-54 vs 55-59. The treatment letters were started to sent out to all eligible individuals since 2004. There was a test phase before and we therefore exclude the year 2003 from the estimations, implying that pre-reform years include 2001 and 2002, while post-reform years are 2004-2010. The explanatory variable of interest is the interaction between the treatment indicator and the dummy indicating the post-reform years. This coefficient estimates the differential evolution in private retirement savings between the treatment and control group after the treatment. Coefficients measure the effect in Euro. Standard errors in parentheses are robust and clustered on the tax unit level. Significance levels are ${ }^{*}<0.1,{ }^{* *}<0.05,{ }^{* * *}<0.01$. Data come from German tax returns, 2001-2010. 
Table 11: DiD Estimates: Salience vs Info - Savings of the Husband

(1) (2)

Dep. Variable Riester Savings of Husband

\begin{tabular}{lcc} 
Age range & $23-30$ & $50-59$ \\
\hline \multicolumn{3}{l}{ Panel A: Salience and Information Effect } \\
\multicolumn{3}{l}{ Husband older than wife } \\
Post $\times$ Treat & $17.53^{* *}$ & $35.42^{* * *}$ \\
& $(7.73)$ & $(2.03)$ \\
Treat & -0.55 & $-2.48^{* * *}$ \\
& $(1.44)$ & $(0.56)$ \\
\hline Adj. $R^{2}$ & 0.11 & 0.04 \\
Obs. & 20871 & 997955
\end{tabular}

Panel B:

Panel B: Salience Effect

Wife older than husband

\begin{tabular}{lcc}
\hline Post $\times$ Treat & $\begin{array}{c}1.14 \\
(1.12)\end{array}$ & $\begin{array}{l}18.28^{* * *} \\
(4.92)\end{array}$ \\
Treat & $3.56^{*}$ & $-3.89^{* *}$ \\
& $(2.16)$ & $(1.55)$ \\
\hline Adj. $R^{2}$ & 0.08 & 0.03 \\
Obs. & 4329 & 191846 \\
& & \\
\hline Treat group & $27-30$ & $50-54$ \\
Year F.E. & yes & yes \\
Controls & yes & yes \\
Pre years & $2001-02$ & $2001-02$ \\
Post years & $2004-10$ & $2004-10$
\end{tabular}

Notes: DiD regressions based on equation 1. Outcome variable: Contributions to private retirement account ('Riester') of the husband. Married couples where either the husband is older than the wife or vice versa. Lower and higher age cutoff. The treatment is receiving a pension information letter. The treatment letters were started to sent out to all eligible individuals since 2004. There was a test phase before and we therefore exclude the year 2003 from the estimations, implying that pre-reform years include 2001 and 2002, while post-reform years are 2004-2010. The explanatory variable of interest is the interaction between the treatment indicator and the dummy indicating the post-reform years. This coefficient estimates the differential evolution in private retirement savings between the treatment and control group after the treatment. Coefficients measure the effect in Euro. Standard errors in parentheses are robust and clustered on the tax unit level. Significance levels are ${ }^{*}<0.1,{ }^{* *}<0.05,{ }^{* * *}<0.01$. Data come from German tax returns, 2001-2010. 
Table 12: DiD Estimates: Salience vs Info - Savings of the Wife

(1) (2)

Dep. Variable Riester Savings of Wife

\begin{tabular}{|c|c|c|}
\hline Age range & $23-30$ & $50-59$ \\
\hline \multicolumn{3}{|c|}{ Panel A: Salience and Information Effect } \\
\hline \multicolumn{3}{|c|}{ Wife older than husband } \\
\hline \multirow[t]{2}{*}{ Post $\times$ Treat } & 14.36 & $21.62^{* * *}$ \\
\hline & $(8.82)$ & $(3.21)$ \\
\hline \multirow[t]{2}{*}{ Treat } & 0.94 & $-3.19^{* * *}$ \\
\hline & $(1.62)$ & $(0.88)$ \\
\hline Adj. $R^{2}$ & 0.109 & 0.042 \\
\hline Obs. & 4314 & 190283 \\
\hline
\end{tabular}

\begin{tabular}{|c|c|c|}
\hline \multicolumn{3}{|c|}{ Panel B: Salience } \\
\hline \multicolumn{3}{|c|}{ Husband older than wife } \\
\hline \multirow[t]{2}{*}{ Post $\times$ Treat } & $15.21^{* * *}$ & $10.48^{* * *}$ \\
\hline & $(3.87)$ & $(1.49)$ \\
\hline \multirow[t]{2}{*}{ Treat } & 0.47 & $-1.88^{* * *}$ \\
\hline & $(0.85)$ & $(0.36)$ \\
\hline Adj. $R^{2}$ & 0.082 & 0.045 \\
\hline Obs. & 20795 & 989524 \\
\hline Treat group & $27-30$ & $50-54$ \\
\hline Year F.E. & yes & yes \\
\hline Controls & yes & yes \\
\hline Pre years & 2001-02 & 2001-02 \\
\hline Post years & $2004-10$ & $2004-10$ \\
\hline
\end{tabular}

Notes: DiD regressions based on equation 1. Outcome variable: Contributions to private retirement account ('Riester') of the wife. Married couples where either the husband is older than the wife or vice versa. Lower and higher age cutoff. The treatment is receiving a pension information letter. The treatment letters were started to sent out to all eligible individuals since 2004. There was a test phase before and we therefore exclude the year 2003 from the estimations, implying that pre-reform years include 2001 and 2002, while post-reform years are 2004-2010. The explanatory variable of interest is the interaction between the treatment indicator and the dummy indicating the post-reform years. This coefficient estimates the differential evolution in private retirement savings between the treatment and control group after the treatment. Coefficients measure the effect in Euro. Standard errors in parentheses are robust and clustered on the tax unit level. Significance levels are ${ }^{*}<0.1,{ }^{* *}<0.05,{ }^{* * *}<0.01$. Data come from German tax returns, 2001-2010. 
Table 13: DiD estimates - lower and higher age cutoff - Charitable donations

\begin{tabular}{lcc}
\hline \hline & \multicolumn{2}{c}{$(1)$} \\
Dep. Variable & \multicolumn{2}{c}{ Donations } \\
Age range & $23-30$ & $50-59$ \\
\hline Post $\times$ Treat & $-8.43^{* * *}$ & -25.37 \\
& $(2.83)$ & $(22.27)$ \\
& & \\
Treat & 3.60 & -1.91 \\
& $(4.08)$ & $(20.25)$ \\
West Germany & $8.89^{* *}$ & -106.49 \\
& $(4.49)$ & $(66.59)$ \\
Married & $20.15^{* *}$ & $-229.95^{* * *}$ \\
& $(8.50)$ & $(86.42)$ \\
Children & 4.71 & $-116.10^{*}$ \\
& $(5.36)$ & $(66.21)$ \\
Income & $14.95^{* *}$ & $147.76^{* * *}$ \\
& $(6.24)$ & $(47.55)$ \\
\hline Treat group & $27-30$ & $50-54$ \\
Year F.E. & yes & yes \\
Pre years & $2001-02$ & $2001-02$ \\
Post years & $2004-10$ & $2004-10$ \\
\hline Adj. $R^{2}$ & 0.04 & 0.17 \\
Obs. & 185261 & 1634536 \\
\hline \hline
\end{tabular}

Notes: DiD regressions based on equation 1. Outcome variable: Charitable Donations. Lower and upper age cutoff. The treatment is receiving a pension information letter. Treatment and control ages: $23-26$ vs $27-30 ; 50-54$ vs $55-59$. The treatment letters were started to sent out to all eligible individuals since 2004. There was a test phase before and we therefore exclude the year 2003 from the estimations, implying that pre-reform years include 2001 and 2002, while postreform years are 2004-2010. The explanatory variable of interest is the interaction between the treatment indicator and the dummy indicating the post-reform years. This coefficient estimates the differential evolution in private retirement savings between the treatment and control group after the treatment. Coefficients measure the effect in Euro. Standard errors in parentheses are robust and clustered on the tax unit level. Significance levels are ${ }^{*}<0.1,{ }^{* *}<0.05,{ }^{* * *}<0.01$. Data come from German tax returns, 2001-2010. 
Table 14: DiD estimates - lower and higher age cutoff - Labor earnings

\begin{tabular}{lcc}
\hline \hline & $(1)$ & $(2)$ \\
Dep. Variable & \multicolumn{2}{c}{ Labor Earnings } \\
Age range & $23-30$ & $50-59$ \\
\hline Post $\times$ Treat & $2520.00^{* * *} 1839.83^{* * *}$ \\
& $(207.64)$ & $(295.87)$ \\
& & \\
Treat & $5018.06^{* * *} 1517.02^{* * *}$ \\
& $(152.68)$ & $(245.48)$ \\
West Germany & $6101.87^{* * *} 9334.72^{* * *}$ \\
& $(141.27)$ & $(176.77)$ \\
Married & $16400.47^{* * * 4} 1596.79^{* * *}$ \\
& $(201.03)$ & $(159.18)$ \\
Children & $-7505.06^{* * *} 6904.15^{* * *}$ \\
& $(197.43)$ & $(163.47)$ \\
\hline Treat group & $27-30$ & $50-54$ \\
Year F.E. & yes & yes \\
Pre years & $2001-02$ & $2001-02$ \\
Post years & $2004-10$ & $2004-10$ \\
\hline Adj. $R^{2}$ & 0.15 & 0.051 \\
Obs. & 185276 & 1634740 \\
\hline \hline
\end{tabular}

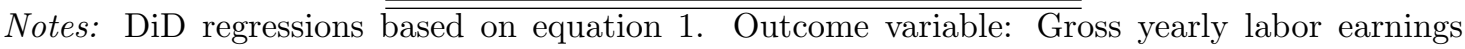
of tax unit. Lower and upper age cutoff. The treatment is receiving a pension information letter. Treatment and control ages: $23-26$ vs $27-30 ; 50-54$ vs $55-59$. The treatment letters were started to sent out to all eligible individuals since 2004. There was a test phase before and we therefore exclude the year 2003 from the estimations, implying that pre-reform years include 2001 and 2002, while post-reform years are 2004-2010. The explanatory variable of interest is the interaction between the treatment indicator and the dummy indicating the post-reform years. This coefficient estimates the differential evolution in private retirement savings between the treatment and control group after the treatment. Coefficients measure the effect in Euro. Standard errors in parentheses are robust and clustered on the tax unit level. Significance levels are ${ }^{*}<0.1$, ${ }^{* *}$ $<0.05,{ }^{* * *}<0.01$. Data come from German tax returns, 2001-2010. 